\title{
Endocrine Pharmacology Research in India: Scientific Progress in Last Five Years
}

\author{
K SRINIVASAN and S S SHARMA* \\ Department of Pharmacology and Toxicology, National Institute of Pharmaceutical Education and \\ Research (NIPER), Sector 67, S.A.S. Nagar (Mohali) 160 062, Punjab, India
}

(Received on 30 August 2017; Accepted on 11 December 2017)

\begin{abstract}
During the last five years, significant scientific effort has been made in the field of endocrine pharmacology by Indian researchers. Endocrine disorders like diabetes and disorders of the reproductive systems and melatonin are the major areas of research interest of the Indian scientists. Though the researchers have investigated both natural products and synthetic compounds, the reported studies have focused primarily on plant extracts to substantiate their use scientifically based on their folklore use. Diabetes is fast gaining the status of a potential epidemic in India with approximately 69 million people in the world. Various pharmacological investigations on herbal and synthetic compounds have been carried out for the treatment of diabetes and its complications. Saroglitazar, a novel PPAR $\alpha / \gamma$ agonist is the first indigenously developed synthetic antidiabetic drug by an Indian pharmaceutical company as approved for the treatment of type 2 diabetes in June 2013. The potential of certain cell based therapies and nanoformulations were also investigated for different diabetes treatment. The scientific rationale for the use of various herbs on male and female reproduction with respect to aphrodiasic, fertility and antifertility properties has been explored. In addition to role of melatonin in chronobiology, it has been reported to possess multiple pharmacological actions such as antioxidant, anti-inflammatory and neuroprotective actions. Only few Indian scientists have studied on endocrine pharmacology related to adrenal, tyroid and parathyroid gland disorders. In addition, the effects of some endocrine disruptors, toxic chemicals and heavy metals on endocrine systems were also studied. In this review, we have compiled the research articles on scientific progress made in the field of endocrine pharmacology from India between years 2012-2017.
\end{abstract}

Keywords: Endocrine Pharmacology; Diabetes; Reproduction; Melatonin, Endocrine Disruptors

\section{Introduction}

The scientific progress in the field of endocrinology is greatly linked with the efforts made by the researchers working in the area of endocrine pharmacology. Even though research work relevant to endocrine glands had started much earlier, this branch of science gained major attention only when Brown Sequard published "organotherapy", which was initially carried out with testicular extracts. Other animal glands such as the adrenal, thyroid and pancreas were also used with varying degrees of success to treat hormone deficiency. Improvements in chemistry, pharmacy, and allied sciences led to innovations in endocrine pharmacology. Researchers began using a variety of compounds, both natural and synthetic, to treat endocrinopathies. As our understanding of the pathophysiological basis of metabolic and hormonal diseases improved, newer drugs were invented on purpose, rather than discovered by chance. The field of endocrine pharmacology has also witnessed the pharmacological exaptation meaning that some endocrine drugs, apart from their indications for the treatment of endocrinopathies, are also shown to be effective and indicated for the treatment of other nonendocrine ailments (Kalra et al., 2012, Katare and Banerjee 2016). Similarly, certain non-endocrine drugs have also been exapted for the treatment of endocrine disorders. In this review, we have analyzed and compiled the research articles published by the researchers from India between years 2012-2017 in the field of endocrine pharmacology. There are only some institutions and laboratories in India that keep

\footnotetext{
*Author for Correspondence: E-mail: sssharma@niper.ac.in; shyamsharma14@yahoo.com
} 
working in the area of endocrine pharmacology. The main research areas of the Indian scientists were on diabetes and other disorders associated with reproductive system and melatonin. As we focused more on the pharmacological research in the field of endocrine pharmacology, few important clinical reports have only been incorporated in this review.

\section{Diabetes Mellitus}

Diabetes mellitus, a chronic metabolic noncommunicable disease has attained epidemic proportions worldwide. As of 2015, more than 415 million adults have diabetes and this number is expected to increase to around 642 million by the end of 2040. India is one of the epicentres of the global diabetes mellitus epidemic and has the second highest number of people with the disease in the world ( $\sim 69$ million individuals as of 2015) after China (IDF 2015, Unnikrishnan et al., 2016). Despite the current use of synthetic drugs and progress being made in allopathic drug research and development as reviewed, the use of herbal remedies is gaining importance because of synthetic drugs have drawbacks and limitations (Chaudhury et al., 2017, Kumar and Bharti 2017). Many of the pharmacological investigations from India during the last 5 years (2012-17) have been undertaken on the effects of herbal and natural products on diabetes. The conventional and induced animal models of diabetes such as high dose streptozotocin (STZ) and combined high fat diet (HFD) and low dose STZ-induced animals were mostly used in the studies.

\section{Antidiabetic Investigations on Herbal Drugs and Natural Products}

Various plants and herbal products have been used as a folk medicine in India for the treatment of diabetes. Many of the pharmacological investigations were carried out to provide a scientific rationale for the use of the plant to treat diabetes in folk medicine (Table 1). The ethyl extract of Ficus carica leaves was evaluated in HFD-fed and low dose STZ-treated type 2 diabetic rats. It exhibited significant antidiabetic effects by restoring the altered carbohydrate metabolizing enzymes such as glucose6-phosphatase, fructose-1,6-bisphosphatase and hexokinase in the liver tissue of HFD/STZ diabetic rat (Stephen Irudayaraj et al., 2017). Further, ficusin isolated from $F$. carica is reported to produce antidiabetic effects via enhancing glucose transporter (GLUT)-4 translocation and peroxisome proliferatoractivated receptor (PPAR)- $\gamma$-expression in adipose tissue (Irudayaraj et al., 2016). The ethanolic extract of Allium cepa stimulates GLUT4 translocationmediated glucose uptake by the activation of the phosphatidylinositol 3-kinase (PI3K)/Akt dependent pathway (Gautam et al., 2015).

Oral administration of Aegle marmelos (L.) Corr. bark extract showed significant hypoglycaemic activity which was associated with reduction in blood glucose, increase in insulin levels and pancreatic $\beta$ cells regeneration in STZ-induced diabetic rats (Gandhi et al., 2012). Aegeline, alkaloidal-amide isolated from Aegle marmelos exhibited antihyperglycemic activity which may be via stimulating glucose transport and cytoskeletal rearrangement through PI3K/Rac1 signaling (Gautam et al., 2015). The aqueous extract of tamarind seeds selectively increased GLUT-2 (liver), GLUT-4 (skeletal muscle), islets' intracellular calcium levels and $\beta$-cell neogenesis resulting in improved glucose homeostasis in STZ diabetic rats (Sole and Srinivasan 2012). The anti-inflammatory action of tamarind seeds contributes toward its antidiabetic activity via repressing pancreatic beta-cell damage and normalizing sterol regulatory element-binding transcription factor (SREBP-1c) concentration in liver (Sole et al., 2013).

Polyphenols-rich Cyamopsiste tragonoloba (L.) Taub. beans were reported to possess hypoglycemic and $\beta$-cells protective effects in HFD/ STZ type 2 diabetic rats (Gandhi et al., 2014). The investigators from Annamalai University have demonstrated that oral treatments of some plant derived components such as myrtenal (monoterpene) and naringin (flavonoid) caused significant reduction in the levels of plasma glucose, blood glycosylated hemoglobin (HbA1c) and improvement in plasma insulin. Myrental acts by enhancing GLUT2 in liver, GLUT4 and Akt in the skeletal muscle where as naringin acts by modulating hepatic enzymes involved in carbohydrate metabolism of diabetic rats (Pari and Chandramohan 2017, Rathinam and Pari 2016).

Prasath and co-workers from the University of Madras have made extensive studies on antidiabetic 
Table 1

\begin{tabular}{|c|c|c|c|c|c|c|c|c|}
\hline $\begin{array}{l}\text { Botanical } \\
\text { name }\end{array}$ & Family & $\begin{array}{l}\text { Common } \\
\text { name }\end{array}$ & $\begin{array}{l}\text { Part/extract } \\
\text { used }\end{array}$ & $\begin{array}{l}\text { Active } \\
\text { ingredient/ } \\
\text { principle(s) }\end{array}$ & Test model & Pharmacological effects & Suggested mode of action(s) & References \\
\hline Ficus carica $\mathrm{I}$ & Moraceae & Fig/Anjir & $\begin{array}{l}\text { Leaves/ethyl } \\
\text { acetate }\end{array}$ & Ficusin & $\begin{array}{l}\text { HFD fed-low } \\
\text { dose STZ- } \\
\text { induced type } \\
2 \text { diabetic rats }\end{array}$ & $\begin{array}{l}\text { Decrease }(\downarrow) \text { in blood glucose, total } \\
\text { cholesterol (TC), triglycerides (TG), } \\
\text { and increase }(\uparrow) \text { in hepatic glycogen }\end{array}$ & $\begin{array}{l}\text {-Restoring carbohydrate metabolizing } \\
\text { enzymes in liver } \\
\text {-Enhancing GLUT- } 4 \text { translocation- } \\
\text { mediated glucose uptake and } \\
\text { PPAR- } \gamma \text { expression in adipose tissue }\end{array}$ & $\begin{array}{l}\text { Stephen } \\
\text { Irudayaraj et al., } \\
\text { 2017; Irudayaraj } \\
\text { et al., } 2016\end{array}$ \\
\hline Allium cepa & $\begin{array}{l}\text { Amarylli- } \\
\text { daceae }\end{array}$ & Onion & $\begin{array}{l}\text { Whole } \\
\text { onion/ } \\
\text { ethanol }\end{array}$ & $\begin{array}{l}\text { Allyl propyl } \\
\text { disulphide } \\
\text { and Diallyl- } \\
\text { disulphide }\end{array}$ & In-vitro & $\begin{array}{l}\text {-Stimulates glucose uptake by the rat } \\
\text { skeletal muscle cells (L6 myotubes) }\end{array}$ & $\begin{array}{l}\text {-Stimulating GLUT4 translocation and } \\
\text { glucose disposal by the activation } \\
\text { of PI3K/Akt dependent pathway }\end{array}$ & $\begin{array}{l}\text { Gautam et al., } \\
2015\end{array}$ \\
\hline $\begin{array}{l}\text { Aegle } \\
\text { marmelos }\end{array}$ & Rutaceae & Bael & $\begin{array}{l}\text { Bark/ } \\
\text { Methanol }\end{array}$ & $\begin{array}{l}\text { Aegelin and } \\
\text { Lupeol }\end{array}$ & $\begin{array}{l}\text { STZ-induced } \\
\text { diabetic rats }\end{array}$ & $\begin{array}{l}\downarrow \text { blood glucose, } \uparrow \text { insulin and } \\
\text { pancreatic } \beta \text {-cells regeneration }\end{array}$ & $\begin{array}{l}\text {-Stimulating the glucose transport } \\
\text { through Akt/Rac1 pathway in the } \\
\text { skeletal muscle cells }\end{array}$ & $\begin{array}{l}\text { Gandhi et al., } \\
\text { 2012; Gautam } \\
\text { et al., } 2015\end{array}$ \\
\hline $\begin{array}{l}\text { Tamarindus } \\
\text { indica }\end{array}$ & Fabaceae & Tamarind & $\begin{array}{l}\text { Seeds/ } \\
\text { Aqueous }\end{array}$ & $\begin{array}{l}\text { Polyphenols } \\
\text { and } \\
\text { Flavonoids }\end{array}$ & $\begin{array}{l}\text { Neonatal STZ- } \\
\text { induced } \\
\text { diabetic rats }\end{array}$ & $\begin{array}{l}\downarrow \text { blood glucose, } \uparrow \text { insulin and } \\
\text { pancreatic } \beta \text {-cells regeneration } \\
\downarrow \text { serum NO, HbA1c and TNF- } \alpha\end{array}$ & $\begin{array}{l}\text {-Improving GLUT-2 and SREBP-1c } \\
\text { in the liver and GLUT- } 4 \text { in the } \\
\text { skeletal muscles }\end{array}$ & $\begin{array}{l}\text { Sole and } \\
\text { Srinivasan 2012; } \\
\text { Sole } \text { et al., } 2013\end{array}$ \\
\hline \multirow[t]{6}{*}{$\begin{array}{l}\text { Cyamopsis } \\
\text { tetragonoloba }\end{array}$} & Fabaceae & $\begin{array}{l}\text { Guar/ } \\
\text { cluster } \\
\text { Bean }\end{array}$ & $\begin{array}{l}\text { Beans/ } \\
\text { methanol }\end{array}$ & $\begin{array}{l}\text { Polyphenols } \\
\text { (gallic acid } \\
\text { and caffeic } \\
\text { acid) }\end{array}$ & $\begin{array}{l}\text { HFD/STZ- } \\
\text { type } 2 \\
\text { diabetic rats }\end{array}$ & $\begin{array}{l}\text { hypoglycemic and } \beta \text {-cells } \\
\text { protective effects }\end{array}$ & -- & $\begin{array}{l}\text { Gandhi et al., } \\
2014\end{array}$ \\
\hline & & & & Myrental & $\begin{array}{l}\text { STZ-diabetic } \\
\text { rats }\end{array}$ & $\begin{array}{l}\downarrow \text { plasma glucose, } \mathrm{HbA} 1 \mathrm{c} \text { and } \\
\uparrow \text { plasma insulin }\end{array}$ & $\begin{array}{l}\text {-Enhancing GLUT2 in liver, GLUT4 } \\
\text { and Akt in the skeletal muscle }\end{array}$ & $\begin{array}{l}\text { Rathinam and } \\
\text { Pari } 2016\end{array}$ \\
\hline & & & & Naringin & $\begin{array}{l}\mathrm{HFD} / \mathrm{STZ}- \\
\text { type } 2 \text { diabetic } \\
\text { rats }\end{array}$ & $\begin{array}{l}\downarrow \text { plasma glucose, } \mathrm{HbA} 1 \mathrm{c} \text { and } \\
\uparrow \text { plasma insulin and blood } \mathrm{Hb}\end{array}$ & $\begin{array}{l}\text {-Modulating hepatic glucose } \\
\text { metabolism }\end{array}$ & $\begin{array}{l}\text { Pari and } \\
\text { Chandramohan } \\
2017\end{array}$ \\
\hline & & & & $\begin{array}{l}\text { Fisetin }(3,7, \\
\text { 3', 4'-tetrahy- } \\
\text { droxyflavone) }\end{array}$ & $\begin{array}{l}\text { STZ-induced } \\
\text { diabetic rats }\end{array}$ & $\begin{array}{l}\downarrow \text { blood glucose, lipids, HbA1c and } \\
\uparrow \text { circulating insulin }\end{array}$ & $\begin{array}{l}\text {-Inhibiting gluconeogenic enzymes } \\
\text { in hepatic and renal tissues } \\
\text {-Antioxidant and anti-inflammatory } \\
\text { actions via decreasing NF-kB p65, } \\
\text { IL-1 } \beta \text {, and lipid peroxidation }\end{array}$ & $\begin{array}{l}\text { Prasath and } \\
\text { Subramanian } \\
\text { 2014; Prasath } \\
\text { et al., 2014; } \\
\text { Prasath and } \\
\text { Subramanian } \\
\text { 2013; Prasath } \\
\text { et al., } 2013\end{array}$ \\
\hline & & & & $\begin{array}{l}\text { Rosmarinic } \\
\text { acid } \\
\text { (polyphenol) }\end{array}$ & $\begin{array}{l}\mathrm{HFD} / \mathrm{STZ}- \\
\text { type } 2 \text { diabetic } \\
\text { rats }\end{array}$ & $\begin{array}{l}\downarrow \text { blood glucose, lipids, HbA1c, } \\
\text { AGE, TNF- } \alpha, \text { IL-1 } \beta, \text { IL } 6, \text { NO, } \\
\uparrow \text { plasma insulin and } \uparrow \text { insulin } \\
\text { sensitivity index }\end{array}$ & $\begin{array}{l}\text { - Alleviating pancreatic } \beta \text {-cell } \\
\text { dysfunction via increasing Nrf- } 2 \text { and } \\
\text { hemeoxyenase (HO-1) antioxidants } \\
\text { levels }\end{array}$ & $\begin{array}{l}\text { Govindaraj and } \\
\text { Sorimuthu Pillai } \\
\text { 2015; Jayanthy } \\
\text { et al., } 2017\end{array}$ \\
\hline & & & & Morin & STZ-diabetic & $\downarrow$ blood glucose, lipids and $\uparrow$ serum & -Antihyperglycemic action via & Vanitha et al., \\
\hline
\end{tabular}




\begin{tabular}{|c|c|c|c|c|c|c|c|c|}
\hline & & & & $\begin{array}{l}\text { (pentahydro- } \\
\text { xyflavone), } \\
\text { and Zinc- } \\
\text { Morin } \\
\text { complex }\end{array}$ & $\begin{array}{l}\text { rats } \\
\text { HFD/STZ } \\
\text { diabetic rats }\end{array}$ & $\begin{array}{l}\text { insulin and preservation of } \beta \text {-cells } \\
\downarrow \text { insulin resistance and } \uparrow \text { plasma } \\
\text { adiponectin and } \downarrow \text { leptin and } \\
\text { TNF- } \alpha \text { levels }\end{array}$ & $\begin{array}{l}\text { ameliorating hepatic glucose metabo- } \\
\text { lizing enzymes } \\
\text {-acting as antioxidant against } \\
\text { pancreatic } \beta \text {-cells damage by Nrf } 2 \\
\text { signaling pathway }\end{array}$ & $\begin{array}{l}\text { 2014; } \\
\text { Sendraya- } \\
\text { perumal } \text { et al., } \\
\text { 2014; Vanitha } \\
\text { et al., } 2017\end{array}$ \\
\hline $\begin{array}{l}\text { Embelia } \\
\text { ribes }\end{array}$ & $\begin{array}{l}\text { Myrsina- } \\
\text { ceae }\end{array}$ & $\begin{array}{l}\text { False black } \\
\text { pepper }\end{array}$ & $\begin{array}{l}\text { Fruits/ } \\
\text { Chloroform }\end{array}$ & $\begin{array}{l}\text { Embelin and } \\
\text { its derivatives } \\
\text { 6-bromoembe- } \\
\text { lin and vilangin }\end{array}$ & $\begin{array}{l}\mathrm{HFD} / \mathrm{STZ} \\
\text { diabetic rats }\end{array}$ & $\begin{array}{l}\text { Embelin decreases blood glucose, } \\
\downarrow \text { TC, TG and FFA, } \downarrow \text { hyperinsu- } \\
\text { linemia, insulin resistance, } \beta \text {-cell } \\
\text { dysfunction }\end{array}$ & $\begin{array}{l}\text {-Partial agonism on PPAR- } \gamma \text { and } \\
\text { stimulating glucose uptake in adipose } \\
\text { tissue } \\
\text {-Normalizing the hepatic glucose } \\
\text { metabolizingenzymes }\end{array}$ & $\begin{array}{l}\text { Gandhi et al., } \\
\text { 2013; Stalin } \\
\text { et al., } 2016\end{array}$ \\
\hline $\begin{array}{l}\text { Enicostemm- } \\
\text { alittorale }\end{array}$ & $\begin{array}{l}\text { Gentiana- } \\
\text { ceae }\end{array}$ & $\begin{array}{l}\text { Mamejava/ } \\
\text { white head }\end{array}$ & -- & $\begin{array}{l}\text { Swertiamarin } \\
\text { (a secoiridoid } \\
\text { glycoside) }\end{array}$ & $\begin{array}{l}\text { STZ-diabetic } \\
\text { rats }\end{array}$ & $\begin{array}{l}\text { Swertiamarin decreases }(\downarrow) \text { blood } \\
\text { glucose, } \downarrow \text { HbA1c, TC, TG, LDL, } \\
\text { and } \uparrow H b \text {, plasma insulin }\end{array}$ & $\begin{array}{l}\text {-Antihyperlipidemic, } \\
\text {-Antihyperglycemic } \\
\text {-Cytoprotective }\end{array}$ & $\begin{array}{l}\text { Dhanavathy } \\
2015\end{array}$ \\
\hline $\begin{array}{l}\text { Lactuca } \\
\text { sativa }\end{array}$ & Asteraceae & Lettuce & $\begin{array}{l}\text { Leaves/ } \\
\text { DCM+ } \\
\text { methanol+ } \\
\text { water }\end{array}$ & $\begin{array}{l}\text { Lactuca- } \\
\text { xanthin }\end{array}$ & $\begin{array}{l}\text { STZ-diabetic } \\
\text { rats }\end{array}$ & $\downarrow$ blood glucose & $\begin{array}{l}\text { Intestinal } \alpha \text {-amylase and } \alpha \text {-glucosidase } \\
\text { inhibitory activity }\end{array}$ & $\begin{array}{l}\text { Gopal et al., } \\
2017\end{array}$ \\
\hline $\begin{array}{l}\text { Murraya } \\
\text { koenigii }\end{array}$ & Rutaceae & $\begin{array}{l}\text { Curry } \\
\text { leaves }\end{array}$ & -- & $\begin{array}{l}\text { Koenidine } \\
\text { (carbazole } \\
\text { alkaloid) }\end{array}$ & $\begin{array}{l}\mathrm{db} / \mathrm{db} \text { mice and } \\
\mathrm{STZ} \text { diabetic } \\
\text { rats }\end{array}$ & $\begin{array}{l}\text { koenidine } \downarrow \text { blood glucose } \uparrow \text { insulin } \\
\text { sensitivity }\end{array}$ & $\begin{array}{l}\text {-Enhancing GLUT4 translocation via } \\
\text { AKT-dependent signaling pathway }\end{array}$ & Patel et al., 2016 \\
\hline $\begin{array}{l}\text { Mimosa } \\
\text { pudica }\end{array}$ & $\begin{array}{l}\text { Mimosa- } \\
\text { ceae }\end{array}$ & $\begin{array}{l}\text { Sleepy } \\
\text { plant/ } \\
\text { Touch-me- } \\
\text { not }\end{array}$ & $\begin{array}{l}\text { Stem/ } \\
\text { methanol }\end{array}$ & Myoinositol & $\begin{array}{l}\text { HFD/STZ- } \\
\text { type } 2 \text { diabetic } \\
\text { rats }\end{array}$ & $\begin{array}{l}\text { Myoinositol } \downarrow \text { blood glucose, } \\
\uparrow \text { insulin sensitivity, } \downarrow \text { TC, TG } \\
\text { and LDL-c }\end{array}$ & $\begin{array}{l}\text {-Enhancing expression of PPAR } \gamma \text {, } \\
\text { GLUT4 and insulin receptor (IR) } \\
\text { signaling molecules in the adipose } \\
\text { tissue }\end{array}$ & $\begin{array}{l}\text { Antony et al., } \\
2017\end{array}$ \\
\hline $\begin{array}{l}\text { Costus } \\
\text { igneus }\end{array}$ & Costaceae & $\begin{array}{l}\text { Spiral flag/ } \\
\text { Insulin } \\
\text { plant }\end{array}$ & $\begin{array}{l}\text { Leaves/ } \\
\text { methanol }\end{array}$ & $\begin{array}{l}\text { Orally active } \\
\text { insulin-like } \\
\text { protein (ILP) }\end{array}$ & $\begin{array}{l}\text { STZ-induced } \\
\text { diabetic Swiss } \\
\text { mice }\end{array}$ & $\begin{array}{l}\text { ILP } \downarrow \text { blood glucose and improving } \\
\text { oral glucose tolerance }\end{array}$ & $\begin{array}{l}\text { Oral insulin mimetic via increasing } \\
\text { cytoplasmic IRS-1 and GLUT-4 } \\
\text { translocation }\end{array}$ & $\begin{array}{l}\text { Hardikar et al., } \\
\text { 2016; Joshi et al., } \\
2013\end{array}$ \\
\hline $\begin{array}{l}\text { Syzygium } \\
\text { cumini }\end{array}$ & Myrtaceae & Jamun & $\begin{array}{l}\text { Seed/ } \\
\text { aqueous }\end{array}$ & Vitalboside A & $\begin{array}{l}\text { HFD/STZ- } \\
\text { type } 2 \text { diabetic } \\
\text { rats }\end{array}$ & $\begin{array}{l}\downarrow \text { serum glucose, } \downarrow \text { hyperinsulinemia, } \\
\text { dyslipidemia, TNF- } \alpha \text { and insulin } \\
\text { resistance } \\
\downarrow \text { pancreatic oxidative stress } \\
\text { parameters, } \uparrow \text { antioxidant enzyme } \\
\text { activities and } \beta \text {-cell functions }\end{array}$ & $\begin{array}{l}\text {-Modulating PPAR } \gamma \text { and PPAR } \alpha \\
\text {-Inhibiting PTP1B }\end{array}$ & $\begin{array}{l}\text { Sharma et al., } \\
\text { 2012; } \\
\text { Thiyagarajan } \\
\text { et al., } 2016\end{array}$ \\
\hline $\begin{array}{l}\text { Mitragyna- } \\
\text { parvifolia }\end{array}$ & Rubiacea & $\begin{array}{l}\text { Kadamb/ } \\
\text { Kaim }\end{array}$ & -- & $\begin{array}{l}6,17 \text {-dihydro- } \\
17 b \text {-hydroxy } \\
\text { isomitraphy- } \\
\text { lline(a indole } \\
\text { alkaloid) }\end{array}$ & $\begin{array}{l}\text { Neonatal STZ } \\
\text { type } 2 \\
\text { diabetic rats }\end{array}$ & $\begin{array}{l}\downarrow \text { plasma glucose, } \uparrow \text { glucose tolerance, } \\
\uparrow \text { GLP- } 1, \text { IL-10 and } \beta \text {-cell } \\
\text { proliferation }\end{array}$ & -Inhibiting DPP IV & $\begin{array}{l}\text { Shukla and } \\
\text { Srinivasan } 2012\end{array}$ \\
\hline
\end{tabular}

tumor necrosis factor-a; LDL-low density lipoprotein; FFA-free fatty acids; AGE-advanced glycation end products; DCM-dichloromethane; Nrf2-nuclear factor erythroid 2-related

factor 2; IRS-insulin receptor substrate,GLP-glucagon like peptide-1; PTP1B-protein tyrosine phosphatase-1B; DPP IV-dipeptidylpeptidase-IV;IL- interleukin 
effects of fisetin, tetrahydroxyflavones (polyphenol) isolated from strawberries. Fisetin treatment significantly reduced blood glucose, lipids, HbA1c, nuclear factor (NF)-kB p65 unit (in pancreas) and interleukin (IL)-1 $\beta$ (plasma), serum nitric oxide (NO) along with an elevation in circulating insulin in STZinduced diabetic rats. Fisetin improves glucose homeostasis through the inhibition of gluconeogenic enzymes in hepatic tissues (Prasath and Subramanian 2014, Prasath et al., 2014). The treatment also improved the antioxidant status in pancreas, plasma (Prasath et al., 2013) and also in liver (Prasath and Subramanian 2013) of diabetic rats indicating the antioxidant potential of fisetin.

Rosmarinic acid, a polyphenol, modulates the antioxidant status and protects pancreatic tissues from glucolipotoxicity-mediated oxidative stress in HFD/ STZ diabetic rats (Govindaraj and Sorimuthu Pillai 2015). It significantly inhibited insulin resistance in skeletal muscle cells by enhancing mitochondrial biogenesis (Jayanthy et al., 2017). The effects of morin (2',3,4',5,7-pentahydroxyflavone), an potent natural antioxidant was evaluated in STZ-induced type 1 diabetic rats. Morin significantly reduced the blood glucose and improved the serum insulin levels along with preservation of pancreatic $\beta$-cell population. It caused reduction in glucose-6-phosphatase and fructose-1,6-bisphosphatase along with the increase in liver hexokinase and glucose-6-phosphate dehydrogenase activities (Vanitha et al., 2014). Similar antidiabetic potential was also demonstrated for zincmorin, a metal flavonol complex in HFD/STZ type 2 diabetic rats (Sendrayaperumal et al., 2014). The antidiabetic effect of morin was partly due to its antioxidant effects against oxidative stress-induced DNA damage in pancreatic $\beta$-cells by activating the nuclear factor erythroid 2-related factor 2 (Nrf2) signaling pathway (Vanitha et al., 2017).

Embelin, a quinone derivative isolated from Embelia ribes Burm (Myrsinaceae) fruit was shown to regulate insulin resistance, alter $\beta$-cell dysfunction and modulate key markers involved in insulin sensitivity and glucose transport in type 2 diabetic rats. Embelin improved insulin sensitivity via partial agonistic action of PPAR- $\gamma$ and glucose uptake through translocation and activation of GLUT4 in adipose tissue via PI3K/ pAkt (Akt also known as protein kinase B) signalling pathway (Gandhi et al., 2013). The derivatives of embelin such as 6-bromoembelin and vilangin are also reported to be having similar anti-diabetic effects (Stalin et al., 2016). Swertiamarin, a secoiridoid glycoside, is reported to possess anti-hyperglycemic, anti-hyperlipidemic, cytoprotective, and immune reactivity and also have a broad spectrum potential of treating diabetes and other diabetic complications (Dhanavathy 2015).

Therapeutic potential of pterostilbene was also demonstrated against pancreatic $\beta$-cell apoptosis in diabetes via mediating through $\mathrm{Nrf} 2$ (Bhakkiyalakshmi et al., 2014, Sireesh et al., 2017). Lactucaxanthin, a potential anti-diabetic carotenoid from lettuce (Lactuca sativa) has been shown to inhibit $\alpha$-amylase and $\alpha$-glucosidase activity in vitro and in diabetic rats (Gopal et al., 2017). Patel and co-workers have identified and evaluated koenidine as one of the naturally occurring carbazolealkaloids from Murraya koenigii as a metabolically stable antidiabetic compound in $\mathrm{db} / \mathrm{db}$ type 2 diabetic mice. It showed a considerable reduction in the postprandial blood glucose profile with an improvement in insulin sensitivity (Patel et al., 2016). Myoinositol isolated from Mimosa pudica Linn. (Mimosaceae) stem methanol extract exhibited anti-diabetic effects which was attributed to enhanced level of PPAR- $\gamma$ expression in the adipose tissue, upregulation of GLUT4 and insulin receptor signaling molecules (Antony et al., 2017).

The researchers from Pune have recently studied the antidiabetic property of insulin-like protein (ILP) purified from Costus igneus belonging to family Costaceae from Western ghats of India. It was demonstrated to be orally active and exhibiting hypoglycaemic effects comparable to insulin given intraperitoneally (i.p.) in STZ-induced diabetic mice. It acts through insulin signaling pathways (Hardikar et al., 2016, Joshi et al., 2013). Syzygium cumini ameliorates insulin resistance and $\beta$-cell dysfunction via modulating PPAR, dyslipidemia, oxidative stress, and tumor necrosis factor (TNF)- $\alpha$ in HFD/STZinduced type 2 diabetic rats (Sharma et al., 2012). Bioactivity-based fractionation and purification of Syzygium cumini seeds led to the isolation and identification of bifunctional vitalboside A. It was reported to possess antidiabetic and anti-adipogenic activities via inhibition of protein tyrosine phosphatase1B (PTP1B) and partial agonism to PPAR- $\gamma$ in silico 
and in vitro (Thiyagarajan et al., 2016).

Glucagon like peptide-1 (GLP-1) is known to stimulate insulin secretion, insulin biosynthesis and insulin gene transcription. Shukla and Srinivasan from DIPSAR, New Delhi have shown the inhibitory effects of 16,17-dihydro-17b-hydroxy isomitraphylline, a indole alkaloid isolated from Mitragyna parvifolia on DPPIV (an enzyme involved in GLP degradation). It exhibited antidiabetic effects which was associated withreduced plasma glucose concentration, increased glucose tolerance associated with increase in GLP-1, IL-10 levels and $\beta$-cell proliferation in neonatal STZ type 2 diabetic rats (Shukla and Srinivasan 2012).

In addition, some of the polyherbal formulations (PHF) likehydroalcoholic extracts of four plants namely Salacia oblonga, Salacia roxbhurgii, Garcinia indica and Lagerstroemia parviflora (Subhasree et al., 2015) and MAC-ST/001 (Yadav et al., 2013) were reported to reverse most blood and tissue changes caused by experimental diabetes. Antidiabetic potential of yet another polyherbal formulation, DB14201 has also been demonstrated in experimental models of diabetes (Gopalakrishna Pillai et al., 2017).

\section{Antidiabetic Investigations on Synthetic Agents}

Akarte and others have shown the antidiabetic effects of vildagliptin, a DPPIV inhibitor which was asscociated with increase in islets blood flow, insulin secretions and inhibition of the excessive NO and peroxynitrite ions formation resulting in protection of pancreatic $\beta$ cells in diabetic rats (Akarte et al., 2012). They have also demonstrated the potent antidiabetic effects of a novel long acting potent, selective DPPIV inhibitor, PKF-275-055 (1, 3, and $10 \mathrm{mg} / \mathrm{kg})$, an analog of vildagliptin in neonatal STZ induced type 2 diabetic rat model (Akarte et al., 2012). Another novel long-acting DPPIV inhibitor, ZYDPLA1 was also reported to be effective in preclinical models and has potential to become once-a-week therapy for treatment of type 2 diabetes (Jain et al., 2015). Dhanesha and co-workers have recently investigated the effect of combination of glucokinase activator (piragliatin) with GLP-1 receptor agonist exendin-4 in male $\mathrm{db} / \mathrm{db}$ mice. The chronic treatment with exendin4 , has been shown to improve the antidiabetic efficacy and reverses hepatic steatosis in glucokinase activator treated db/db mice (Dhanesha et al., 2013).
The researchers from Hamdard University have recently synthesized and demonstrated the antidiabetic activity of 2,4-thiazolidinedione based amide derivatives without significant hepatotoxicity in vitro and in vivo as compared to rosiglitazone and pioglitazone as reference drugs (Naim et al., 2017). Recently, the anti-diabetic, anti-oxidant and antiinflammatory properties of 2-[(4-chlorobenzyl) amino]-4-methyl-1,3-thiazole-5-carboxylic acid (BAC) a new thiazole derivative were also demonstrated in a neonatal STZ diabetic rats (Paudel et al., 2017).

Jain and others from Zydus Cadila, Ahmedabad have demonstrated that saroglitazar, a novel dual PPAR $\alpha / \gamma$ agonist exhibits lipid-lowering and insulinsensitizing effects in different preclinical models of diabetes (Jain et al., 2015). Saroglitazar is the first indigenously developed molecule by any Indian pharmaceutical company approved for the treatment of type 2 diabetes by the Drug Controller General of India in June 2013 and is marketed under the trade name Lipaglyn. Saroglitazar has predominant PPAR$\alpha$ and moderate PPAR- $\gamma$ activity and its combined receptor activation resulted in significant anti-diabetic and antidyslipidemic effects. Saroglitazar has demonstrated no significant adverse effects like weight gain and edema that are commonly identified with similar molecules like the glitazone class of drugs. The better tolerability and absence of significant side effects could be due to the absence of thiazolidinedione (TZD) ring in saroglitazar molecule.Recent observational study has reported that the use of saroglitazar, for a period of 14 weeks, was associated with significant improvement in both glycaemic and lipid parameters among Indian patients with type 2 diabetes (Chatterjee, Majumder and Ray 2015, Ramakrishnan 2015).

The discovery of potent, selective and orally bioavailable triaryl-sulfonamide based PTP1B inhibitors for the treatment of type 2 diabetes was also reported in vitro and in vivo (Patel et al., 2012). Gowda and co-workers from Connexios Life Sciences Pvt Ltd, Bangalore showed the therapeutic potential of CNX-011-67, a highly selective, potent and orally bioavailable G-protein-coupled receptor 40 (GPR40) agonist in controlling diabetes and other metabolic parameters in Zucker diabetic fatty (ZDF) rats (Gowda et al., 2013). CNX-011-67 significantly 
stimulated glucose metabolism, enhanced glucose responsiveness and increased insulin secretion in a non-genetic neonatal STZ type 2 diabetic models suggesting its potential for the treatment of type 2 diabetes (Sunil et al., 2014). Its beneficial effects in diabetes is also due to its inhibitory action on glucagon secretion from pancreatic islets in vitro (Verma et al., 2014) and anti-inflammatory effects against inflammation-induced $\beta$-cell apoptosis (Verma et al., 2014).

AMP activated protein kinase (AMPK) regulates the coordination of anabolic and catabolic processes. It was also reported that CNX-012-570, a direct AMPK activator provided strong glycemic and lipid control along with significant reduction in body weight in diet-induced obese mice and $\mathrm{db} / \mathrm{db}$ mice models (Anil et al., 2014). The investigation from CDRI, Lucknow showed the discovery of biaryl-4carbonitriles as antihyperglycemic agents that may act through AMP-activated protein kinase (AMPK)p38 MAPK pathway (Goel et al., 2014). Treatment with these compounds improved glucose tolerance, fasting as well as postprandial blood glucose, serum total triglycerides, and increased high-density lipoprotein-cholesterol in different genetic and nongenetic animal models of diabetes.

In addition, antidiabetic effects of some vitamins, minerals and fatty acids have been reported. Vitamin D3 supplementation significantly increased insulin level by regulating altered inositol triphosphate (IP3) and glutamatergic $\alpha$-amino-3-hydroxy-5-methyl-4isoxazolepropionic acid (AMPA) receptor expression in the pancreatic islets of STZ-induced diabetic rat (Jayanarayanan et al., 2015). There is recently renewed interest over advantages of zinc supplementation. The scientists from CFTRI, Mysore have provided the scientific evidence that zinc supplementation alleviates severity of hyperglycemia and associated metabolic abnormalities like hypoinsulinemia, insulin resistance, and altered pancreatic morphology in STZ-induced diabetic rats (Barman and Srinivasan 2016). Chromium picolinate has been shown to attenuate hyperglycemia via modulating hepatic glucose metabolism and hyperglycemia-induced oxidative stress in STZinduced diabetic rats (Sundaram et al., 2012, Sundaram et al., 2013). Khan and Jena have demonstrated the protective role of sodium butyrate, a short chain fatty acid, a histone deacetylases (HDAC) inhibitor on $\beta$-cell proliferation, function and glucose homeostasis through modulation of p38/ERK MAPK and apoptotic pathways in a juvenile STZ diabetic rat (Khan and Jena 2014). Sodium butyrate has also been shown to reduce insulin-resistance, fat accumulation and dyslipidemia and restores glucose homeostasis through HDAC inhibition and histone acetylation in HFD/STZ type-2 diabetic rat (Khan and Jena 2016). Valproic acid, yet another HDAC inhibitor have also yielded similar results as it improves $\beta$-cell proliferation, function as well as reduces $\beta$-cell apoptosis in juvenile diabetic rats (Khan and Jena 2016).

Diazepam has been shown to potentiate the antidiabetic, antistress and anxiolytic activities of metformin in type-2 diabetes with co-occurring stress in STZ diabetic animals. The combination significantly attenuated combined diabetes and stress-induced hyperglycemia, hypercorticosteronemia, anxiety-like behavior and insulin resistance compared to monotherapy suggesting that metformin in combination with diazepam may be a better therapeutic option in the management of type 2 diabetes with cooccurring stress condition (Garabadu and Krishnamurthy 2014). The co-administration of curcumin capsules with glyburide may be beneficial to the patients in better glycaemic control. The lipid lowering and antidiabetic properties of the curcumin was shown as a potential future drug molecule (Neerati et al., 2014).

\section{Potential of Cell Based Therapy in Diabetes}

Islet transplantation is a promising cell therapy for patients with diabetes, but it is currently limited by the reliance upon cadaveric donor tissue (Viswanathan and Sarang 2013). The researchers from Navi Mumbai have studied the human embryonic stem cell (ECS) differentiation into insulin secreting $\beta$-cells for diabetes. ESC, when differentiated into pancreatic $\beta$ ILC (islet-like clusters), have enormous potential for the cell transplantation therapy for type 1 diabetes. The cells were also found to ameliorate hyperglycaemia in STZ-induced diabetic NOD/SCID (non-obese diabetic/severe combined immunodeficiency) mouse up to 96 days of transplantation (Bose et al., 2012). The administration of mesenchymal stem cell (MSCs) in non-irradiated 
diabetic Wistar rats reduced hyperglycaemia and was accompanied by increased islet-neogenesis, possibly through trans-differentiation/fusion (Bhansali et al., 2015). The investigators from PGIMER, Chandigarh have recently examined the efficacy and safety of autologous bone marrow-derived mesenchymal stem cells (ABM-MSCs) and mononuclear cells (ABMMNCs) transplantation in type 2 diabetic patients and found that there was sustained reduction in insulin doses and improvement in insulin sensitivity with MSCs and increase in C-peptide response with MNCs (Bhansali et al., 2017). Dave and other colleagues have reported that combined therapy of insulinproducing cells and haematopoietic stem cells offers better diabetic control than with only haematopoietic stem cells' infusion for patients with insulindependent diabetes (Dave et al., 2014, Dave et al., 2015).

\section{Pharmacological Investigations in the Area of Diabetic Complications}

Long term diabetes leads to various microvascular (e.g. neuropathy, nephropathy) and macrovascular (corondary heart disease, peripheral vascular disease, stroke) complications associated with structural damage and dysfunctions of various organs that account for most of the morbidity and mortality associated with the disease. We have here in focussed on some of the main complications like diabetesinduced neuropathy, nephropathy and cardiac dysfunctions where mainly Indian scientists are working.

Diabetic Neuropathy : Diabetic neuropathies are nerve damaging disorders associated with diabetes mellitus. Diabetic rats demonstrated the mechanical allodynia and thermal hyperalgesia with reduced nerve perfusion and conduction velocity as compared to control. MDL 28170, calpain inhibitor was reported to confer electrophysiological, nociceptive and biochemical improvement against diabetic neuropathic pain (Kharatmal et al., 2015). It showed the beneficial effects via modulation of tetrodotoxin-resistant sodium channels (TTX-R Na${ }^{(+)}$) kinetics and reduction of oxidative stress and neuro-inflammation. The effect of rufinamide, an antiepileptic drug was also reported against diabetic neuropathy as it improves functional and behavioral deficits via blockade of TTX- $\mathrm{R} \mathrm{Na}^{(+)}$ channels (Kharatmal et al., 2015). The researchers from Hyderabad showed that the treatment with A769662, AMPK activator significantly improved mechanical/thermal hyperalgesia threshold and neurological deficits in STZ rat model of diabetic neuropathy. AMPK activation significantly abolished the NF- $\kappa \mathrm{B}$-mediated neuroinflammation, stimulated peroxisome proliferator-activated receptor gamma coactivator 1-alpha (PGC-1 $\alpha$ )-directed mitochondrial biogenesis and autophagy induction (Yerra and Kumar 2017). Fisetin, a phytoflavonoid confers neuroprotection against diabetic neuropathy in rats by modulating Nrf2 and NF-kB pathways (Sandireddy et al., 2016). The protective effect of EGb 761, a standardized extract of Ginkgo biloba was demonstrated on STZ-induced neuropathic pain in rats by inhibiting oxidative and nitrosative stress (Taliyan and Sharma 2012).

Diabetic Nephropathy : Diabetic nephropathy is a common microvascular complication of diabetes and an important cause of chronic kidney disease (Sharma et al., 2017). The researchers from IITR (CSIR), Lucknow have recently studied the effect of mixture of flavonoids (baicalin and chrysin) in STZinduced diabetes and found that it is protective against diabetic tubular injury by modulating receptor of advanced glycation end products (RAGE), oxidative stress and inflammation (Singh et al., 2017).

The investigators from Guwahati showed that the treatment with methanolic leaf extract of Paederia foetida and some plant derived active principles like diosmin (flavones) and piceatannol (stilbenoid) provided remarkable renoprotection in diabetes by abrogating oxidative stress, NF-kB activation and neuro-inflammation in rat model of diabetic nephropathy (Ahmed et al., 2016, Borgohain et al., 2017, Borgohain et al., 2017). The protective effect of diosgenin, a steroidal saponin, was also demonstrated in diabetes-induced early kidney injury (Kanchan et al., 2016). Ellagic acid, a polyphenol present abundantly in fruits and vegetable significantly inhibited AGE accumulation in the diabetic rat kidney and ameliorated AGE-mediated pathogenesis of diabetic nephropathy (Raghu et al., 2016). Gallic acid is able to ameliorate renal functions by inhibiting the activation of $\mathrm{p} 38$ MAPK in type 2 diabetic rats (Ahad et al., 2015). Recently, taraxerol, a pentacyclic triterpenoid, from Abroma augusta leaves has been reported to attenuate diabetic nephropathy in HFD/ 
STZ type 2 diabetic rats (Khanra et al., 2017). Sodium valproate was reported to ameliorate diabetes-induced fibrosis and renal damage by the inhibition of HDAC in STZ diabetic rats (Khan et al., 2015).

Diabetes-associated Cardiovascular Dysfunctions : The role of protease-activated receptor (PAR) in diabetic cardiomyopathy has recently been evaluated. Treatment with argatroban, a direct thrombin inhibitor attenuates cardiac dysfunctions by reducing fibrosis, inflammation, apoptosis, and PAR expression in heart of HFD/STZ type 2 diabetic rats (Bulani and Sharma 2017). The oral administration of garlic in STZ induced diabetic rats produced cardioprotective effects through activating sirtuin (SIRT)3-MnSOD pathway and ameliorating oxidative stress and mitochondrial dysfunction (Sultana et al., 2016). The researchers from IICT, Hyderabad also showed that administration of garlic, resveratrol, and metformin in diabetic rat decreased pancreatic $\beta$-cell damage and hepatic injury along with restoration of many of the altered metabolic and oxidative stress parameters (Kaur et al., 2016). Resveratrol ameliorates cardiac oxidative stress in diabetes through deacetylation of NFkB-p65 and histone 3 (Bagul et al., 2015).

Levosimendan, a calcium sensitizer significanlty reduced myocardial damage and improved cardiodysfunctions in STZ-induced diabetic cardiomyopathy via sarco/endoplasmic reticulum $\mathrm{Ca}^{2+}$-ATPase/sodium-calcium exchanger (SER CA2a/NCX1) pathway (Akhtar et al., 2016). Chrysin, a PPAR- $\gamma$ agonist improved myocardial injury in diabetic rats through inhibiting AGE-RAGE mediated oxidative stress and inflammation (Rani et al., 2016). Genistein ameliorated cardiac inflammation and oxidative stress in STZ-induced diabetic cardiomyopathy in rats (Gupta et al., 2015). Esculetin alone and in combination with telmisartan was reported to exert beneficial effects in attenuating insulin resistance, cardiac fibrosis damage and vascular hyper responsiveness in type 2 diabetes rats (Kadakol et al., 2015, Kadakol et al., 2015). Diabetes also increases the risk of stroke and augments brain damage after ischemia/reperfusion (I/R).3-bromo-7nitroindazole, selective neuronal nitric oxide synthase (nNOS) inhibitor ameliorated brain I/R injury after middle cerebral artery occlusion in HFD/STZ diabetic rats via inhibition of endoplasmic reticulum stress and apoptosis (Srinivasan and Sharma 2012).

Diabetic Encephalopathy : Apartfrom its deleterious effects on peripheral organs, long term diabetes also leads to central nervous system complications like diabetic encephalopathy and diabetes-associated cognitive decline. The researchers from NIPER, S.A.S. Nagar have reported that NF$\kappa B$ inhibition using pharmacological inhibitors such as BAY 11-7082 (BAY) and parthenolide ameliorated cognitive deficits in experimental HFD/STZ type 2 diabetic rat models through modulating cAMP response element binding (CREB), neuroinflammation and glutamate/GABA neurotransmitters pathway (Datusalia and Sharma 2016, Khare et al., 2017). In addition, derivatives of spices like cinnamaldehyde (a principal component of cinnamon oil) and eugenol (main active principle of cloves) have also been reported to be beneficial in ameliorating neuroinflammation, neurotransmitters homeostasis and oxidative stress in diabetic rat brains (Jawale et al., 2016, Prasad et al., 2016). The researchers from Pune have recently elucidated dual mode of action of eugenol in combating diabetes as it lowers blood glucose by inhibiting $\alpha$-glucosidase and prevents AGE formation by binding to $\varepsilon$-amine group on lysine, protecting it from glycation (Singh et al., 2016). Apart from its neuroprotective effects, genistein, an isoflavone phytoestrogen has been shown to ameliorate diabetes associated cognitive decline due to its modulatory effects on neuroinflammation, acetylcholinesterase activity and oxidative stress in diabetic mice (Rajput and Sarkar 2017). Researchers from Varanasi have recently provided evidences towards molecular basis of the memory enhancing and antidiabetic role of CDRI-08, a well characterized fraction of Bacopa monnieri extract in STZ-induced diabetic mice. It acts via ameliorating alterations in hippocampal oxidative stress and expression of AMPA receptor GluR2 subunit (Pandey et al., 2015).

Potential of Nanoformulations for the Treatment of Diabetes : Recently, different nano formulations of herbal and synthetic compounds have been developed mainly aiming at improving their bioavailability and efficacy as deemed to be effective treatment approach for the control of diabetes and diabetic complications.

Oral delivery of insulin may make treatment more 
convenient and significantly improve the quality of life of diabetes patients who routinely receive insulin by the subcutaneous route. The oral delivery of insulin remains a challenging task as insulin gets degraded by enzymes in gastrointestinal tract resulting in lack of absorption. Jain and co-workers have demonstrated the novel approach for enhancing the oral absorption and hypoglycemic activity of insulin via encapsulation in folate-(FA) coupled polyethyleneglycol (PEG)ylated polylactide-co-glycolide (PLGA) nanoparticles (FAPEG-PLGA NPs). This oral nanoformulation of insulin $(50 \mathrm{U} / \mathrm{kg}$ ) exhibited a twofold increase in the oral bioavailability (double hypoglycemia) without any hypoglycemic shock as compared to subcutaneously administered standard insulin solution in STZ diabetic rats (Jain et al., 2012). The improved stability and antidiabetic potential of insulin containing folic acid functionalized polymer stabilized multilayered liposomes following oral administration was also reported in vivo (Agrawal et al., 2014). Sharma and others have explored the surface engineered and ligand anchored nanobioconjugate as an effective therapeutic approach (by incorporating insulin in concanavalin A anchored PEGylated nanoconstructs) for the oral delivery of insulin in experimental diabetic rats (Sharma et al., 2015).

In addition, some of the nanoformulations of plant based active principles like quercetin (polyphenol), glycyrrhizin (active constituent of the roots and rhizomes of Glycyrrhiza glabra) were also reported to be more efficacious in diabetic rats (Chitkara et al., 2012, Rani et al., 2017). Self nano emulsifying drug delivery system (SNEDDS) curcumin formulation has been characterized that has prolonged plasma exposure and bioavailability and further enhanced efficacy as compared to plain curcumin in STZ-induced diabetic neuropathy in vivo (Joshi et al., 2013). The protective effect of selenium nanoparticles (SeNPs) against the progression of type 1 diabetic nephropathy was reported via quenching oxidative stress as well as by activating cytoprotective protein heat shock protein (HSP70) and longevity protein SIRT1 (Kumar et al., 2014).

\section{Reproductive Endocrine Pharmacology}

\section{Male Reproduction}

Studies on Male Contraceptive and Antifertility Effects of Herbal Drugs: The contraceptive efficacy of Cuminum cyminum isolated fractions was investigated in male albino rats. The chronic administration of it showed the marked decrease in the spermateogenesis associated with decreased counts in round spermatids, preleptotene spermatocytes, secondary spermatocytes and decline in testosterone levels (Saxena et al., 2015).

The ethanolic extract of Pistia stratiotes and its active phytoconstituent, saponin were shown as potential male contraceptive. It showed significant anti-spermatogenic activity as evident from reduction in the weight of reproductive organs, sperm count, sperm viability and serum testosterone (Singh et al., 2014).

The stem bark methanol extract of Thevetia peruviana (Apocynaceae) exhibited antifertility potential in male albino rats and its effects was associated with the reduction in the weight of reproductive organs, decline in different spermatogenic elements, mature Leydig cells and also reduction in sperm density and motility (Gupta et al., 2011). The antifertility effects of aqueous extracts of various plants such as Dalbergia sissoo, Coccinia indica and Mimusops elengi were demonstrated that caused reversible suppression of spermatogenesis and fertility without detectable toxic effects in Parkes strain male mice (Verma and Singh 2014, Verma and Singh 2017). The administration of ethanolic leaf extract of Citrus limon (500 and 1,000 mg/kg/day) for 35 days caused suppression of spermatogenesis which may be due to germ cell apoptosis and decreased production of testosterone in Parkes mice (Singh and Singh 2016). The antifertility effects of methanolic bark extract of Aegle marmelos (L.) was also demonstrated in male Wistar rats (Agrawal et $a l ., 2012$ ). Recent investigations have provided scientific rationale of piperine, an active constituent present in the Piper species of its use for male contraceptive and antifertility effects. Piperine interacts with androgen receptor and androgen binding protein in vitro. It exhibits reversible antispermatogenic effect of piperine on epididymis and seminal vesicles of rat (Chinta and Periyasamy 2016, Chinta et al., 2015).

Studies on Male Aphrodiasic, Fertility and Chemoprotective Effects of Herbal Drugs: The root extracts of Salvia haematodes (5, 50 and $300 \mathrm{mg} / \mathrm{kg}$, orally for 30 days) and Asparagus 
adscendens $(100,200$, and $300 \mathrm{mg} / \mathrm{kg}$ orally for 30 days) significantly increased anabolic, reproductive function and sexual behavioral performance in male rats in dose dependent manner, providing the scientific rationale for their traditional use as an aphrodisiac for sexual disorders (Bansode et al., 2014, Bansode et al., 2015).

The aphrodisiac and spermatogenic potential of alkaloid enriched fraction of Hygrophila spinosa T. ander were also shown in rats. Its treatment led to the increased serum testosterone level resulting in higher number of spermatozoa in testicular lumen as well as increased libido (Vyas and Raval 2016). The alkylamide-rich ethanol solution extract Anacyclus pyrethrum showed the aphrodisiac, androgenic and spermatogenic potential which may improve male fertility by enhancing spermatogenesis (Sharma et al., 2013). Interestingly, the biphasic effect of aqueous extract of Syzygium aromaticum flower buds on reproductive physiology of male mice has been demonstrated. Lower dose of S. aromaticum $(15 \mathrm{mg} /$ $\mathrm{kg}$ ) is androgenic in nature and increases the serum level of testosterone and sperm function and morphology while higher doses $(30 \mathrm{mg}$ and $60 \mathrm{mg}$ ) adversely affect these parameters (Mishra and Singh 2016). The oral administration of herbo-mineral ayurvedic formulation Afrodet Plus(®) resulted in significant increase in daily sperm production in the testis along with increase in epididymal sperm count and progressive motility without producing any treatment-related adverse effects in male rats (Dhumal et al., 2013). Trigonella foenum-graecum increased testosterone levels up to $46 \%$ in $90 \%$ of the study population and sperm counts and sperm morphology improved in $85.4 \%$ and $14.6 \%$ of the study population, respectively (Maheshwari et al., 2017).

The protective effects of Commelina benghalensis L. and Cissusquadran gularis L. were demonstrated against quinalphos-induced male reproductive toxicity in mice. Quinalphos, an organothiophosphate pesticide causes the disruption of endocrine system by inducing oxidative stress, reduction in level of testicular cholesterol leading to decreased testosterone levels and viable sperm count. Treatments significantly reduced the oxidative stress and prevented inhibition of steroidogenesis thereby preventing male infertility (Kokilavani et al., 2014). Sharma and co-workers demonstrated that the treatment with ethanolic extract of Tribulus terrestris and resveratrol elicit protective effects against cypermethrin-induced reproductive toxicity in male Wistar rats. They ameliorated testicular damage by reducing oxidative stress and by enhancing the level of sex hormones (Sharma et al., 2013, Sharma et al., 2014). The investigators from IVRI, Izatnagar investigated the ameliorative effect of curcumin on imidacloprid-induced male reproductive toxicity in Wistar rats. Imidacloprid, a systemic insecticide treatment resulted in significant decrease in total epididymal sperm count, sperm motility, live sperm count, and increase in sperm abnormalities along with decreased testosterone concentration in testis and plasma which was restored by co-administration with curcumin (Lonare et al., 2016). The experimental findings established the potential of Eugenia jambolana extract as a therapeutically better antioxidant and protective against the adverse effects of anticancer drug cisplatin on testicular function as compared to $\mathrm{N}$-acetylcystein-treated rats (Anand et al., 2015). Significant alterations in serum luteinizing hormone (LH), follicular stimulating hormone (FSH) and testosterone were observed in cisplatin group which were effectively reversed by E. jambolana extract supplementation. Singh and co-workers have recently reported that IN0523 (Urs-12-ene-3 $\alpha, 24 \beta$ diol) a plant based derivative of boswellic acid protects against cisplatin-induced urogenital toxicity via inhibiting the oxidative stress/redox status imbalance (Singh et al., 2017).

Investigators have also studied the protective effects of various plants against diabetes-induced reproductive organs' damage and dysfunctions. Mallotusrox burghianus methanolic extract protects against diabetes-induced oxidative damage of testis. The main compounds of this plant like phenols (bergenin) and terpenes (betulinic acid) and their antioxidant and antidiabetic activities might be responsible for its protection of testes in alloxaninduced diabetic rat model (Roy et al., 2015). Ethanolic seed extract of Mucuna pruriens (Linn.) improved male sexual behavior, libido and potency, sperm parameters and hormone (FSH, LH and testosterone) levels in STZ-induced diabetic male rats (Suresh and Prakash 2012). The corrective role of ethyl acetate fraction of hydro-methanolic extract of seed of Eugenia jambolana on testicular impairment was shown in STZ-induced diabetic male rat (Ghosh 
et al., 2014). The protective effects of Eugenia jambolana is due to its antiapoptotic efficacy on testicular germ cell associated with significant recovery in the glycated haemoglobin, serum testosterone, sperm viability, hypo-osmotic swelling and nuclear chromatin decondensation (Ghosh et al., 2016). Caralluma fimbriata ( $200 \mathrm{mg} / \mathrm{kg}$, for 90 days) prevented all abnormalities of reproductive system induced by the high-fat diet (Gujjala et al., 2016). Fluoride exposure is reported to aggravate the testicular damage and sperm quality in diabetic mice. The administration of ginseng and banaba extracts alone and in combination reversed fluoride-induced toxicity on sperm density, motility, viability and morphology and the testicular biochemical parameters (Sm and Mahaboob Basha 2017).

Studies on Effects of Synthetic Drugs on Male Reproduction : The reversible dose-dependent adverse effects of antibiotic salinomycin on male reproductive system of mice were reported. Salinomycin decreased motility and spermatozoa count with increased number of abnormal spermatozoa leading to infertility. The testosterone and LH levels were decreased in testis but increased in serum at higher doses (Ojo et al., 2013). The combination of ampicillin and sulphasalazine has been shown to produce synergistic and reversible antifertility effects in male rats. A decrease in the parameters related to fertility of males such as sperm count, sperm motility, fertility ratio, serum testosterone level, glycogen and protein content in sexual organs was observed (Gupta et al., 2013). High dose of metronidazole $(500 \mathrm{mg} / \mathrm{kg}$ body weight/day for 28 days) induced reversible deleterious effects on the male reproduction and fertility associated with significant reductions in the weights of the testis and epididymis but without significant changes in serum testosterone levels in male mice (Kumari and Singh 2013). Enrofloxacin treatment significantly decreased testicular weight, total sperm count and viability associated with dose dependent decrease in testosterone level, testicular antioxidant enzymes and increase of lipid peroxidation. Selenium supplementation partially restored oxidative stress and sperm damage without affecting the plasma concentrations of enrofloxacin (Rungsung et al., 2016).

Recently, the authors have demonstrated the protective effects of zinc against lead-induced testicular and epididymal toxicity in Wistar rats. Zinc significantly restored the spermatogenesis and steroidogenesis (Anjum et al., 2017). The protective role of zinc supplementation was shown against diabetes-induced testicular and epididymal damages in rat via improving the levels of Nrf2, SOD1, and glutathione peroxidase 5 (GPX5) (Maremanda et al., 2016). Zinc also protects against cyclophosphamideinduced testicular damage and restores testosterone levels in rat via modulating metallothionein, tesmin and Nrf2 associated antioxidant pathways (Maremanda et al., 2014). The protective effects of troxerutin (100 $\mathrm{mg} / \mathrm{kg}$ ) against nickel-induced testicular toxicity was also demonstrated in male Wistar rats via inhibiting testicular oxidative stress (Elangovan et al., 2016).

The supplementation of testosterone mitigated lead-induced suppressed reproduction in male rats. Testosterone treatment significantly increased epididymal sperm count, motile spermatozoa, viable spermatozoa and also the activity levels of testicular $3 \beta$ - and 173-hydroxysteroid dehydrogenases (HSD) as compared to lead-exposed group (Anjum and Reddy 2014). The significance of estrogen in testicular activities and to find out the mechanism by which it regulates spermatogenesis in mice has been studied. The tamoxifen, a selective estrogen receptor inhibited the estrogenic effect which is responsible for the increased expression of NOS and NO formation in testicular cells leading to germ cell apoptosis and impaired spermatogenesis (Verma and Krishna 2017). Letrozole, a selective aromatase inhibitor/estradiol synthesis inhibitor suppressed spermatogenesis by reducing insulin sensitivity and glucose transport in the testis, but significantly increased testosterone level by promoting gonadotrophin release due to decreased estradiol (Verma and Krishna 2017). The presence of $\beta$ endorphin, a naturally occurring opioid peptide, and its receptor ( $\mu$-opioid receptor, $\mu \mathrm{OR}$ ) has been reported in rat testes. Mukherjee and Haldar demonstrated the functional role and significance of photoperiodic regulation of $\mu \mathrm{OR}$ in testicular steroidogenesis using naltrexone, a $\mu \mathrm{OR}$ antagonist. Its administration significantly increased the steroidogenic markers and plasma testosterone concentration in goldern Syrian hamster (Mukherjee and Haldar 2015). 
Prostate Gland : The protective effect of bark of different species of Prunus was evaluated against testosterone-induced benign prostatic hyperplasia (BPH). P. domestica showed the most encouraging effect on prostate associated with remarkable antiinflammatory and antioxidant activities. It restored the serum and prostate testosterone level in a similar manner as by finasteride suggesting its action through inhibition of $5 \alpha$-reductase enzyme (Jena et al., 2016). Boerhaavia diffusa ( $100 \mathrm{mg} / \mathrm{kg}$, for 28 days) showed significant inhibition of prostate growth, improved symptoms of prostatic hyperplasia but did not change the serum testosterone level (Vyas et al., 2013). Dietary zinc deficiency (2-4 weeks) affected the prostate structure and enhanced $\mathrm{NO}$ as well as acid phosphatase activities and impaired HSD activities indicating its prominent role in maintaining the prostate integrity (Joshi et al., 2014).

\section{Female Reproductive System}

Pharmacological Studies of Herbal Drugs on Female Reproduction: Abortifacient potential of methanolic extract of Anthocephalus cadamba stem bark was demonstrated in mice. The administration of extract in pregnant mice reduced the number of live fetus, weight and survival ratio of the fetus, number of corpora lutea (CL), progesterone, estradiol and $\mathrm{LH}$ whereas the number of dead fetus, number of mice that aborted, percentage vaginal opening and post-implantation loss increased significantly (Shaikh et al., 2015). Methanolic extract of Thevetia peruviana leaves containing quercetin $0.0326 \%$ and kaempferol $0.138 \%$ exhibited a significant antifertility potential by decreasing the progesterone level (Samanta et al., 2016). The n-butanol fraction of the ethanolic extract of tubers of Pueraria tuberosa exhibited significant antifertility activity in various laboratory animals. The researchers from IICB, Kolkata have recently identified puerarin as the major constituent of $P$. tuberosa and further showed that the oral administration of puerarin post-coitus resulted in complete implantation failure. It is reported as selectiveoestrogen receptor modulator that adversely modulates the endometrial expression of oestrogen receptor- $\alpha$ and $\beta$ resulting in anti-implantation (Saha et al., 2012). This group recently developed poly lactic-co-glycolic acid-encapsulated nano-puerarin and further studied the molecular pathway underlying its anti-implantation effects (Saraswat et al., 2016). The administration of ethanol extract of P. oleracea $\mathrm{L}$. (Portulacea) blocked ovulation by inhibiting cyclooxygenase activity, altered estrous cycle with a prolonged diestrous, increased the uterine muscle weight and ovary weight suggesting its anti-ovulation effect in rats (Londonkar and Nayaka 2013).

The methanolic extract of Artemisia vulgaris leaves was found to have strong anti-implantation activity and estrogenic activity (Shaik et al., 2014). Methanolic extract of Drynaria quercifolia has shown higher efficacy for both abortifacient and antiimplantation performance and also effected hormone release level (Das et al., 2014). The hydroalcoholic leaves extract of Michelia champaca administered orally at dose levels (100 and $200 \mathrm{mg} / \mathrm{kg}$ body weight) exhibited the antifertility activity as evidenced by significant anti-implantation activityin female Wistar rats and estrogenic/anti-estrogenic activity in ovariectomized female rats (Taprial et al., 2013).

The efficacy of novel fenugreek seed extract (Trigonellafoenum-graecum, Furocyst) was studied on premenopausal women diagnosed with polycystic ovarian syndrome (PCOS). It significantly ameliorated the symptoms of PCOS associated with decrease in both ovarian volume and the number of ovarian cysts, significant increases in LH and FSH levels (Swaroop et al., 2015). A study demonstrated that oral administration of high-concentration ashwagandha root extract (HCARE) supplementation may improve sexual function in healthy women (Dongre et al., 2015). The use of dydrogesterone in women with recurrent abortions has been shown to improve pregnancy outcome, such as a reduction in abortions and improved gestational age and baby weight at delivery which were not,however, modulated by Thelper(Th) 1 and Th2 cytokine production (Kumar et al., 2014).

Pharmacological Studies of Synthetic Agents on Female Reproduction : PCOS is a major cause of anovulatory infertility in women in their reproductive age. PCO-mice showed reduced ovarian LH receptor expression, circulating estradiol and progesterone level which was restored by $\mathrm{GnRH}$-agonist resulting in ovulation in PCO-mice and showed more beneficial effect over the use of GnRH-antagonist (Singh et al., 2016). Pandey and co-workers have observed that the administration of buserelin acetate or hCG on day 
12 post-ovulation leads to accessory corpus luteum (CL) formation, improves luteal profile and consequently increases conception rate in buffaloes (Pandey et al., 2013). Oxytocin injections are illegally used for milk let down in cattle thereby causing oral exposure to human population. It has been shown that oral exposure to hormone oxytocin in female Wistar pups lead to anomalies in ovary associated with increased ovarian weight, $\gamma$ globulin, total number of follicles, and number of CLs indicating higher ovulation (Mishra et al., 2013). The treatment with resistin to the vespertilionid bat, Scotophilus heathi caused increase in and rostenedione due to stimulatory effects on 33-HSD, but decrease in estradiol level due to inhibitory effect on aromatase suggesting that obese women through increased resistin synthesis may cause development of non-ovulatory antral follicles through insulin receptor signaling cascade (Singh et al., 2014).

A controlled release delivery system helps to overcome the problem of short life of the leutinizing hormone releasing hormone (LHRH) in blood and avoids use of multiple injections to enhance reproductive efficacy. Chitosan nanoconjugates had a 13 per cent higher and chitosan gold preparation had a 9 percent higher fertilization rate as compared to plain LHRH in female fish (Rather et al., 2013). The recent study reported that the delivery of chitosan nanoconjugated salmon LHRH increased the expression level of Sox 9 transcripts (a primary factor in regulation of gonadal development) in gonads and steroid hormonal levels in blood of male and female walking catfish (Bhat et al., 2016). A recent clinical report suggests that both the combined hormonal vaginal ring (that releases $15 \mu \mathrm{g}$ of ethinylestradiol and $120 \mu \mathrm{g}$ of the 25 etonogestrel per day) with combined hormonal pills (containing $30 \mu \mathrm{gm}$ of EE and $150 \mu \mathrm{gm}$ of levonorgestrel) are very effective short-term treatments for heavy menstrual bleeding in reproductive age group (Dahiya et al., 2016).

The researchers from NII, New Delhi reported the contraceptive efficacy of Escherichia coliexpressed recombinant porcine zona pellucida proteins. Immunization of female mice with these recombinant proteins elicited high antibody titers as well as T-cell responses. Immune sera recognized mouse oocyte also inhibited in vitro fertilization. Immunized mice showed significant decrease in fertility indicating the usefulness of contraceptive vaccine (Gupta et al., 2013). In addition, the second generation anti-epileptic drugs like topiramate and gabapentin adversely affected the reproductive functions in young non-epileptic female rats as ascertained by disturbed hormonal levels and estrous cyclicity as well as alterations in GABAergic system and GnRH neuronal-glial plasticity (Kumar and Kaur 2014).

\section{Pharmacological Studies on Thyroid and Parathyroid Glands}

The researchers from JIPMER, Pondicherry have shown that the extract of Costus pictus (insulin plant) has therapeutic potential in restoring thyroid hormone levels and in preventing the biochemical complications due to thyroid hormone insufficiency in animal model of experimental hypothyroidism (Ashwini et al., 2017). Betulinic acid, a naturally occurring pentacyclic triterpenoid is reported to possess therapeutic potential in chemically induced hypothyroidism model in rats (Afzal et al., 2014).

The anti-thyroid effects of various natural compounds such as rutin, naringin and hesperidin in L-thyroxine (T4)-induced hyperthyroidism have been demonstrated in rats. L-T4 administration significantly enhanced the serum concentrations of thyroxine and triiodothyronine, hepatic 5'-deiodinase I (5'DI) activity, serum lactate dehydrogenase (LDH) and serum glutamic-pyruvic transaminase (SGPT) along with an increase in malondialdehyde (MDA) content in hepatic tissues and depletion of cellular antioxidants. However, on administration of these test flavonoids, these effects were more or less normalized possibly via mediating through their antioxidant actions (Panda and Kar 2014). A gitogenin-type steroidal saponin and 5,7,4'-trihydroxy-6,3' dimethoxy-flavone5-O- $\alpha-1$ rhamnopyranoside isolated from the leaves of Malvastrum coromandelianum and Annona squamosa leaves, respectively are reported to have similar anti-thyroid and antioxidant potential as compared to standard antithyroid drug, propylthiouracil in rat model of thyrotoxicosis (Panda and Kar 2015, Panda and Kar 2016).

It is reported that catechin, a tea flavonoid has potent antithyroid activity as evidenced from decreasedactivities of thyroid peroxidase and thyroidal 5'DI, serum T3 and T4 levels coupled with significant 
elevation of serum thyroid stimulating hormone (TSH) in rats (Chandra and De 2013). Radioactive iodine (I) (RAI) is used widely for the treatment of hyperthyroidism either as a first-line treatment or following relapse after antithyroid drug treatment. The recent pilot study suggested that a short course of lithium is safe and could be beneficial for hyperthyroid patients considered for RAI therapy as it increased the RAI retention in thyroid, and thus had the potential to increase the effect of RAI therapy (Chouhan et al., 2016).

Teriparatide (parathyroid hormone 1-34 [PTH (1-34]), an amide of PTH), is widely available for the use in osteoporosis but is also reported to be effective in the treatment of hypoparathyroidism (Upreti et al., 2017). The oral human parathyroid hormone 1-34 (PTH 1-34) loaded pegylated chitosan and further biocompatible and mucoadhesive thiolated chitosan (TCS) nanoformulation as an alternative patient compliant route in treating osteoporosis have been evaluated both in vitro and in vivo (Narayanan et al., 2013, Narayanan et al., 2014). A novel flavonoid C-glucoside isolated from Ulmus wallichiana protects against glucocorticoid -induced bone loss by promoting osteoblast survival through $\mathrm{p} 53$ inhibition and activation of AKT pathways as compared to human PTH (Khan et al., 2013).

\section{Pharmacological Studies on Adrenal Gland}

The administration of Andrographis paniculata extract and pure andrographolide exhibited protective effects against chronic stress-triggered pathologies in rats. The treatment significantly ameliorated footshock stress-induced alterations in body weight, gastric ulcer, adrenal and spleen weights, plasma cortisol levels, and cytokines in blood and brain (Thakur et al., 2014). The aqueous extract of Cinnamomum tamala Nees and Eberm possesses significant anxiolytic, antidepressant, and anti-stress effects by normalizing the plasma levels of corticosterone, glucose, cholesterol, and triglyceride levels in rats (Upadhyay et al., 2016). The gastro-protective and anti-stress efficacies of monomethyl fumarate and a fumaria indica extract were demonstrated in chronically stressed rats and shown to act as regulators or modulators of monoamine, corticosterone, and cytokine homeostasis (Shakya et al., 2016). The researchers from IIT (BHU),
Lucknow reported that Asparagus racemosus attenuated anxiety-like behavior on different paradigms (open-field test, hole-board, and elevated plus maze tests) in rats via enhancing amygdalar serotonin and norepinephrine levels (Garabadu and Krishnamurthy 2014).

It is reported that anovulation that results from psychological stress is due to increase in cortisol level (Kala and Nivsarkar 2016). It is reported that catecholamines can also modulate ovarian steroidogenic activity in catfish, Heteropneustes fossilis (Joy et al., 2014). Catecholamines stress hormones like epinephrine and norepinephrine regulate energy homeostasis by regulating iron homeostasis in cells (Tapryal et al., 2015). Excess aldosterone is reported to result in decreased glucose uptake and oxidation in skeletal muscle in adult male rat, thus increasing the incidence of type 2 diabetes (Selvaraj et al., 2013). Vitamin C is reported to inhibit etomidateinduced adrenal suppression in patients undergoing cardiac surgery (Das et al., 2016). The potential role of ondansetron (a 5HT3 receptor antagonist) was shown in reversing chronic unpredictable stressinduced depressive behavior, which is possibly mediated by its modulating effects on the HPA-axis and serotonergic system in mice (Gupta et al., 2014).

\section{Pharmacological Studies on Pineal Gland and Role of Melatonin}

Melatonin, also known as $N$-acetyl-5-methoxy tryptamine, is a hormone that is produced by the pineal gland and regulates sleep and wakefulness. In addition to its role in chronobiology, multiple pharmacological effects of melatonin have been reported in mammals. The protective effect of melatonin against metabolic and reproductive disturbances in PCOS was demonstrated in rats. Melatonin $(2 \mathrm{mg} / \mathrm{kg})$ treatment resulted in significant decrease in serum total testosterone and fasting insulin levels (Pai and Majumdar, 2014). Supplementation of melatonin in rat reduced ovariectomy-induced oxidative stress. Melatonin is reported as more potent and safe alternative to estrogen replacement therapy in alleviating postmenopausal increases in oxidative stress and hepatic and renal dysfunction (Baxi et al., 2013). Melatonin pretreatment in carp ameliorates ovaprim actions on the process of oocyte maturation by the enhancing the formation of maturation- 
promoting factor (MPF) and alleviates oxidative stress in pre-ovulatory follicles by stimulating different antioxidants (Moniruzzaman et al., 2016). The protective effect of melatonin was reported against dexamethasone-induced testicular toxicity and germ cell apoptosis and immunosuppression in golden Syrian hamsters and this contributes to enhanced survival of male hamster (Mukherjee et al., 2015, Vishwas et al., 2013).

Melatonin has been shown to have neuroprotective effects in some experimental models of neurodegenerative and neurological disorders like Huntington's disease, cerebral ischemia, peripheral neuropathy and epilepsy (Areti et al., 2017, Bhattacharya et al., 2014, Chakraborty et al., 2014, Rao et al., 2016, Vishnoi et al., 2016, Waseem et al., 2017). Agomelatine, a synthetic melatonin protects against pentylenetetrazole (PTZ)-induced kindling in mice and kindling-associated oxidative stress, depression, and impairment of spatial memory (Azim et al., 2017). Recently, the protective role of nanocapsulated melatonin was studied in cerebral I/ $\mathrm{R}$ of aged brain in rats. It exhibited significantly higher potential to rescue neuronal cells and mitochondria during I/R insult and also restored the activities of antioxidative enzymes and matrix metalloproteinases (Sarkar et al., 2017). The protective effects of melatonin are also reported against other experimental disease models viz. isoproterenol-induced myocardial injury, ulcerative colitis and associated colon carcinogenesis (Mukherjee et al., 2012, Trivedi and Jena 2013, Trivedi et al., 2016). Diabetes-associated neurobehavioural and neurochemical changes were reported to improve by two week administration of melatonin $(3 \mathrm{mg} / \mathrm{kg}$ and $10 \mathrm{mg} / \mathrm{kg})$ alone or in combination with nicotinamide by inhibiting oxidative stress-PARP pathway (Jangra et al., 2013). In HFD fed mice, low dose of melatonin is found to abrogate lipotoxicity-mediated stellate cell activation and hepatic fibrosis progression (Das et al., 2017). Melatonin also confers protective effects in chemotherapy-induced mitochondrial damage in liver of rats, by reducing oxidative stress (Madhu et al., 2015). One week melatonin $(50 \mathrm{mg} / \mathrm{kg} / \mathrm{d}$, i.p.) treatment is also reported to antagonize the memory impairment due to the adverse effects of propoxur poisoning (Mehta et al., 2014). Melatonin has also been shown to be protective against microwave radiations-induced testicular toxicity in rats (Meena et al., 2014) and also ${ }^{60} \mathrm{Co} \gamma$ - irradiation-mediated testicular, hematopoietic, immunological and gastrointestinal injuries in C57BL/ 6 male mice (Khan et al., 2015, Khan et al., 2017).

\section{Endocrine Disruptors, Toxic Chemicals and Heavy Metals}

Endocrine disruptors are chemicals that can interfere with endocrine (or hormone) systems at certain doses. These disruptions can cause cancerous tumors, birth defects, and other developmental disorders. Phthalates are commonly used as plasticizers in a variety of products and are reported as endocrinedisrupting chemicals. Long-term exposure (45 days) of phthalates between pre-pubertal to adult stage significantly affected male fertility by altering both structural and functional integrity of Sertoli cells in testes. Its treatment significantly reduced serum testosterone levels, indicating anti-androgenic nature of the test phthalates (Kumar et al., 2015). Lactational exposure of phthalate was also reported to cause longterm disruption in testicular architecture by altering tight junctional and apoptotic protein expression in Sertoli cells of first filial generation pubertal Wistar rats (Sekaran et al., 2015).

Bisphenol A (BPA) is a well-known endocrine disruptor which represents a major toxicological and public health concern due to its widespread exposure to humans. Tiwari and co-workers have shown that oral administration of bisphenol A (BPA, $10 \mu \mathrm{g}, 5 \mathrm{mg}$ and $50 \mathrm{mg} / \mathrm{kgbw}$ for 6 days) exhibited weak germ cell mutagenic and genotoxic activity that affects male reproductive functions that may be due to oxidative stress (Tiwari and Vanage 2013, Tiwari and Vanage 2017). Deltamethrin is a synthetic pyrethroid insecticide that shows significant harmful effects on testes, liver and kidney. Deltamethrin showed the dose-dependent toxic effects associated with significant histological alteration in the testis, reduction in sperm count, sperm motility, serum testosterone, FSH and LH (Sharma et al., 2014). The exposure of tributyltin (TBT), a common environmental contaminant and endocrine disruptor hinders intracellular cholesterol transport resulting in abnormal sex steroid biosynthesis and subsequent spermatogenic defects in hamsters (Kanimozhi et al., 2014).

The exposure of two endocrine disrupting pesticides viz., Mancozeb and imidacloprid on reproductive behaviors and secondary sexual 
characters in a seasonally breeding wildlife bird, red munia has been studied. Their exposure causes impairment of the lactotropic as well as hypothalamic-pituitary-testicular (HPT) axes that was accompanied with increased plasma prolactin and decreased LH, FSH and testosterone levels (Pandey et al., 2017). BDE-209, a congener of polybrominated diphenyl ethers (PBDEs), a class of brominated flame retardants is having structural similarity with thyroid hormones and acts as an endocrine disruptor by interfering with thyroid homeostasis. Exposure of BDE-209 to adult mice is also reported to cause impaired testicular steroidogenesis due to downregulated expression of steroidogenic factor 1 (SF-1) and suppression of spermatogenesis (Sarkar et al., 2016). The effects of triptolide on reproduction of wild female rodent pest species, Bandicota bengalensis revealed that it affected the histomorphology of uterus by causing a decrease in lumen and columnar cell height and number of uterine glands and ovary by increasing the number of atretic follicles and decreasing the number of developing follicles (Dhar and Singla 2014).

Excess iodine when administered above its tolerable ranges (100 and 500 times more than recommended doses) for prolonged duration acts on thyroid itself developing a state of biochemical hypothyroidism (as evident by low T3) that induces oxidative stress in testis and reduces circulating testosterone level resulting in structural and functional changes of male gonads (Chakraborty et al., 2016). Where as in females, iodine in excess exerts biphasic mode of action depending on the dose (100 and 500 times) in female reproductive physiology and both the doses used in this study affected fertility equally in adult rats (Mahapatra and Chandra 2017). Effect of exposure hexavalent chromium (CrVI), an environmental pollutant was investigated in a rat model. Pregnant Wistar rats were exposed to 50/100/200ppm CrVI through drinking water during embryonic days 9-14. On 120 postnatal days, testes showed increased level of CrIII in sertoli cells and germ cells, serum and testicular interstitial fluid associated with decreased testosterone, seminiferous tubules atrophy and disruption of sertoli cells tight junctions (Kumar et al., 2017). Mother rats exposed to CrVI showed reduced reproductive outcome, while the offsprings showed higher accumulation of $\mathrm{Cr}$ in ovary, altered steroid, and peptide hormones (Samuel et al., 2014).
Titanium di-oxide $\left(\mathrm{TiO}_{2}\right)$ or its nanoparticle has a potential effect on reproduction and fertility due to its accumulation in testicular cells. Intravenous administration of $\mathrm{TiO}_{2}$ nanoparticles induces oxidative stress, which in turn produce cytotoxic and genotoxic changes in sperms along with decrease in the testosterone activity (Meena et al., 2015). Arsenic has a detrimental effect on reproductive system. The higher doses of $\operatorname{arsenic}(\mathrm{V})$ (more than $50 \mathrm{ppm}$ ) were shown to elicit testicular toxicity and impair semen quality by inducing oxidative stress in the testicular microenvironment (Guvvala et al., 2016). Short term copper $(\mathrm{Cu})$ administration has been found to exert deleterious effect on intracellular organelles of rat ovarian cells in vivo. In vitro administration of $\mathrm{Cu}$ in porcine ovarian granulosa cells releases insulin-like growth factor (IGF-I), steroid hormone progesterone, and induces expression of peptides related to proliferation and apoptosis (Roychoudhury et al., 2016). Environmental toxicants such as lead or cadmium and phthalate esters have deteriorating effect on male reproductive system. Recent study showed that lead or cadmium or phthalates might independently contribute to decline in semen quality which include sperm motility, sperm count and sperm DNA damage as well as it affects the level of male sex hormone (Pant et al., 2014). Cadmium chloride also significantly affected the ovarian steroidogenesis and inhibited the secretion of gonadotropin-induced 173-estradiol in female common carp Cyprinus carpio (Das and Mukherjee 2013). Changes in lifestyle lead to insulin resistance in females ultimately predisposing them towards infertility. Cadmium $(\mathrm{Cd})$, also an environmental endocrine disruptor, is reported for detrimental effects on granulosa cells, thus leading to ovarian dysfunction. The combined effect of insulin resistance with $32 \mu \mathrm{M}$ cadmium in granulosa cells demonstrated significant decreases in expression of steroidogenic acute regulatory protein (StAR),

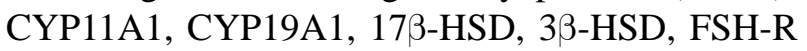
and LH-R. There was a decrease observed in progesterone and estradiol concentrations as compared to control (Belani et al., 2014, Belani et al., 2016).

\section{Acknowledgements}

We acknowledge the help of our Ph.D. students namely Ms Kahkashan Resham, Mr Pavan Thapak and Mr Pratik Adhya for collecting some of the 
information and arranging the references. Despite our best efforts, contributions of some of the authors might have been missed out which is totally inadvertent and we apologize to the authors.

\section{References}

Afzal M, Kazmi I, Semwal S, Al-Abbasi F A and Anwar F (2014) Therapeutic exploration of betulinic acid in chemically induced hypothyroidism Mol Cell Biochem 386 27-34

Agrawal A K, Harde H, Thanki K and Jain S (2014) Improved stability and antidiabetic potential of insulin containing folic acid functionalized polymer stabilized multilayered liposomes following oral administration Biomacro molecules 15 350-360

Agrawal S S, Kumar A, Gullaiya S, Dubey V, Nagar A, Tiwari P, Dhar P and Singh V (2012) Antifertility activity of methanolic bark extract of Aegle marmelos (L.) in male wistar rats Daru 2094

Ahad A, Ahsan H, Mujeeb M and Siddiqui W A (2015) Gallic acid ameliorates renal functions by inhibiting the activation of p38 MAPK in experimentally induced type 2 diabetic rats and cultured rat proximal tubular epithelial cells Chem Biol Interact 240 292-303

Ahmed S, Mundhe N, Borgohain M, Chowdhury L, Kwatra M, Bolshette N, Ahmed A and Lahkar M (2016) Diosmin Modulates the NF-kB Signal Transduction Pathways and Downregulation of Various Oxidative Stress Markers in Alloxan-Induced Diabetic Nephropathy Inflammation 39 1783-1797

Akarte A S, Srinivasan B P and Gandhi S (2012) Relationships between the islets blood flow, nitric oxide, insulin, and cytosolic calcium in rat pancreatic islets: effects of DPPIV inhibitor vildagliptin Eur J Pharm Sci 45 546-551

Akarte A S, Srinivasan B P and Gandhi S (2012) A novel long acting DPP-IV inhibitor PKF-275-055 stimulates betacell proliferation resulting in improved glucose homeostasis in diabetic rats Biochem Pharmacol 83 241-252

Akhtar M S, Pillai K K, Hassan M Q, Dhyani N, Ismail M V and Najmi A K (2016) Levosimendan reduces myocardial damage and improves cardiodynamics in streptozotocin induced diabetic cardiomyopathy via SERCA2a/NCX1 pathway Life Sci 153 55-65

Anand H, Misro M M, Sharma S B and Prakash S (2015) Protective effects of Eugenia jambolana extract versus Nacetyl cysteine against cisplatin-induced damage in rat testis Andrologia 47 194-208

Anil T M, Harish C, Lakshmi M N, Harsha K, Onkaramurthy M, Sathish Kumar V, Shree N, Geetha V, Balamurali G V,
Gopala A S, Madhusudhan Reddy B, Govind M K, Anup M O, Moolemath Y, Venkataranganna M V, Jagannath M $\mathrm{R}$ and Somesh B P (2014) CNX-012-570, a direct AMPK activator provides strong glycemic and lipid control along with significant reduction in body weight; studies from both diet-induced obese mice and $\mathrm{db} / \mathrm{db}$ mice models Cardiovasc Diabetol 1327

Anjum M R and Reddy P S (2014) Recovery of lead induced suppressed reproduction in male rats by testosterone Andrologia 47 560-567

Anjum M R, Madhu P, Reddy K P and Reddy P S (2017) The protective effects of zinc in lead-induced testicular and epididymal toxicity in Wistar rats Toxicol Ind Health $\mathbf{3 3}$ 265-276

Antony P J, Gandhi G R, Stalin A, Balakrishna K, Toppo E, Sivasankaran K, Ignacimuthu S and Al-Dhabi NA (2017) Myoinositol ameliorates high-fat diet and streptozotocininduced diabetes in rats through promoting insulin receptor signaling Biomed Pharmacother 88 1098-1113

Areti A, Komirishetty P, Akuthota M, Malik R A and Kumar A (2017) Melatonin prevents mitochondrial dysfunction and promotes neuroprotection by inducing autophagy during oxaliplatin-evoked peripheral neuropathy J Pineal Res 62

Ashwini S, Bobby Z, Sridhar M G and Cleetus C C (2017) Insulin Plant (Costus pictus) Extract Restores Thyroid Hormone Levels in Experimental Hypothyroidism Pharmacognosy Res 9 51-59

Azim M S, Agarwal N B and Vohora D (2017) Effects of agomelatine on pentylenetetrazole-induced kindling, kindling-associated oxidative stress, and behavioral despair in mice and modulation of its actions by luzindole and 1(m-chlorophenyl) piperazine Epilepsy Behav 72 140-144

Bagul P K, Deepthi N, Sultana R and Banerjee S K (2015) Resveratrol ameliorates cardiac oxidative stress in diabetes through deacetylation of NFkB-p65 and histone $3 \mathrm{~J} \mathrm{Nutr}$ Biochem 26 1298-1307

Bansode F W, Rajendran S M and Singh R K (2014) Dose dependent effects of ethanol extract of Salvia haematodes Wall roots on reproductive function and copulatory behaviour in male rats Andrologia 47 266-275

Bansode F W, Arya K R, Singh R K and Narender T (2015) Dosedependent effects of Asparagus adscendens root (AARR) extract on the anabolic, reproductive, and sexual behavioral activity in rats Pharm Biol 53 192-200

Barman S and Srinivasan K (2016) Zinc supplementation alleviates hyperglycemia and associated metabolic abnormalities in streptozotocin-induced diabetic rats Can J Physiol Pharmacol 94 1356-1365 
Baxi D B, Singh P K, Vachhrajani K D and Ramachandran A V (2013) Melatonin supplementation in rat ameliorates ovariectomy-induced oxidative stress Climacteric 16 274283

Belani M, Purohit N, Pillai P and Gupta S (2014) Modulation of steroidogenic pathway in rat granulosa cells with subclinical Cd exposure and insulin resistance: an impact on female fertility Biomed Res Int 2014460251

Belani M, Shah P, Banker M and Gupta S (2016) Dual effect of insulin resistance and cadmium on human granulosa cellsIn vitro study Toxicol Appl Pharmacol 313 119-130

Bhakkiyalakshmi E, Shalini D, Sekar T V, Rajaguru P, Paulmurugan R and Ramkumar K M (2014) Therapeutic potential of pterostilbene against pancreatic beta-cell apoptosis mediated through Nrf2 Br J Pharmacol 171 1747-1757

Bhansali S, Kumar V, Saikia U N, Medhi B, Jha V, Bhansali A and Dutta P (2015) Effect of mesenchymal stem cells transplantation on glycaemic profile \& their localization in streptozotocin induced diabetic Wistar rats Indian $J$ Med Res 142 63-71

Bhansali S, Dutta P, Yadav M K, Jain A, Mudaliar S, Hawkins M, Kurpad A V, Pahwa D, Yadav A K, Sharma R R, Jha V, Marwaha N and Bhansali A (2017) Autologous bone marrow-derived mononuclear cells transplantation in type 2 diabetes mellitus: effect on beta-cell function and insulin sensitivity Diabetol Metab Syndr 950

Bhat I A, Rather M A, Saha R, Pathakota G B, Pavan-Kumar A and Sharma R (2016) Expression analysis of Sox9 genes during annual reproductive cycles in gonads and after nanodelivery of LHRH in Clarias batrachus Res Vet Sci 106 100-106

Bhattacharya P, Pandey A K, Paul S and Patnaik R (2014) Melatonin renders neuroprotection by protein kinase $\mathrm{C}$ mediated aquaporin-4 inhibition in animal model of focal cerebral ischemia Life Sci 100 97-109

Borgohain M P, Lahkar M, Ahmed S, Chowdhury L, Kumar S, Pant R and Choubey A (2017) Small Molecule Inhibiting Nuclear Factor-kB Ameliorates Oxidative Stress and Suppresses Renal Inflammation in Early Stage of AlloxanInduced Diabetic Nephropathy in Rat Basic Clin Pharmacol Toxicol 120 442-449

Borgohain M P, Chowdhury L, Ahmed S, Bolshette N, Devasani K, Das T J, Mohapatra A and Lahkar M (2017) Renoprotective and antioxidative effects of methanolic Paederia foetida leaf extract on experimental diabetic nephropathy in rats $J$ Ethnopharmacol 198 451-459

Bose B, Shenoy S P, Konda S and Wangikar P (2012) Human embryonic stem cell differentiation into insulin secreting beta-cells for diabetes Cell Biol Int 36 1013-1020

Bulani Y and Sharma S S (2017) Argatroban Attenuates Diabetic Cardiomyopathy in Rats by Reducing Fibrosis, Inflammation, Apoptosis, and Protease-Activated Receptor Expression Cardiovasc Drugs Ther 31 255-267

Chakraborty A, Mandal J, Mondal C, Sinha S and Chandra A K (2016) Effect of Excess Iodine on Oxidative Stress Markers, Steroidogenic-Enzyme Activities, Testicular Morphology, and Functions in Adult Male Rats Biol Trace Elem Res 172 380-394

Chakraborty J, Nthenge-Ngumbau D N, Rajamma U and Mohanakumar K P (2014) Melatonin protects against behavioural dysfunctions and dendritic spine damage in 3nitropropionic acid-induced rat model of Huntington's disease Behav Brain Res 264 91-104

Chandra A K and De N (2013) Catechin induced modulation in the activities of thyroid hormone synthesizing enzymes leading to hypothyroidism Mol Cell Biochem 374 37-48

Chatterjee S, Majumder A and Ray S (2015) Observational study of effects of Saroglitazar on glycaemic and lipid parameters on Indian patients with type 2 diabetes Sci Rep 57706

Chaudhury A, Duvoor C, Reddy Dendi V S, Kraleti S, Chada A, Ravilla R, Marco A, Shekhawat N S, Montales M T, Kuriakose K, Sasapu A, Beebe A, Patil N, Musham C K, Lohani G P and Mirza W (2017) Clinical Review of Antidiabetic Drugs: Implications for Type 2 Diabetes Mellitus Management Front Endocrinol (Lausanne) 86

Chinta G and Periyasamy L (2016) Reversible AntiSpermatogenic Effect of Piperine on Epididymis and Seminal Vesicles of Albino Rats Drug Res 66 420-426

Chinta G, Ramya Chandar Charles M, Klopcic I, Sollner Dolenc M, Periyasamy L and Selvaraj Coumar M (2015) In Silico and In Vitro Investigation of the Piperine's Male Contraceptive Effect: Docking and Molecular Dynamics Simulation Studies in Androgen-Binding Protein and Androgen Receptor Planta Med 81 804-812

Chitkara D, Nikalaje S K, Mittal A, Chand M and Kumar N (2012) Development of quercetin nanoformulation and in vivo evaluation using streptozotocin induced diabetic rat model Drug Deliv Transl Res 2 112-123

Chouhan A, Abhyankar A and Basu S (2016) The feasibility of low-dose oral lithium therapy and its effect on thyroidal radioiodine uptake, retention, and hormonal parameters in various subcategories of hyperthyroid patients: a pilot study Nucl Med Commun 37 74-78

Dahiya P, Dalal M, Yadav A, Dahiya K, Jain S and Silan V (2016) Efficacy of combined hormonal vaginal ring in comparison to combined hormonal pills in heavy menstrual bleeding 
Eur J Obstet Gynecol Reprod Biol 203 147-151

Das B, Dey A, Talukdar A D, Nongalleima K, Choudhury M D and Deb L (2014) Antifertility efficacy of Drynaria quercifolia (L.) J Smith on female Wister albino rats $J$ Ethnopharmacol 153 424-429

Das D, Sen C and Goswami A (2016) Effect of Vitamin C on adrenal suppression by etomidate induction in patients undergoing cardiac surgery: A randomized controlled trial Ann Card Anaesth 19 410-417

Das N, Mandala A, Naaz S, Giri S, Jain M, Bandyopadhyay D, Reiter R J and Roy S S (2017) Melatonin protects against lipid-induced mitochondrial dysfunction in hepatocytes and inhibits stellate cell activation during hepatic fibrosis in mice J Pineal Res 62

Das S and Mukherjee D (2013) Effect of cadmium chloride on secretion of 17beta-estradiol by the ovarian follicles of common carp, Cyprinus carpio Gen Comp Endocrinol 181 107-114

Datusalia A K and Sharma S S (2016) NF-kappaB Inhibition Resolves Cognitive Deficits in Experimental Type 2 Diabetes Mellitus through CREB and Glutamate/GABA Neurotransmitters Pathway Curr Neurovasc Res 13 2232

Dave S D, Trivedi H L, Gopal S C and Chandra T (2014) Combined therapy of insulin-producing cells and haematopoietic stem cells offers better diabetic control than only haematopoietic stem cells' infusion for patients with insulin-dependent diabetes BMJ Case Rep 2014

Dave S D, Vanikar A V, Trivedi H L, Thakkar U G, Gopal S C and Chandra T (2015) Novel therapy for insulin-dependent diabetes mellitus: infusion of in vitro-generated insulinsecreting cells Clin Exp Med 15 41-45

Dhanavathy G (2015) Immunohistochemistry, histopathology, and biomarker studies of swertiamarin, a secoiridoid glycoside, prevents and protects streptozotocin-induced beta-cell damage in Wistar rat pancreas $J$ Endocrinol Invest 38 669-684

Dhanesha N, Joharapurkar A, Shah G, Kshirsagar S, Patel V, Patel K, Bahekar R and Jain M (2013) Treatment with exendin4 improves the antidiabetic efficacy and reverses hepatic steatosis in glucokinase activator treated $\mathrm{db} / \mathrm{db}$ mice Eur $J$ Pharmacol 714 188-192

Dhar P and Singla N (2014) Effect of triptolide on reproduction of female lesser bandicoot rat, Bandicota bengalensis Drug Chem Toxicol 37 448-458

Dhumal R, Vijaykumar T, Dighe V, Selkar N, Chawda M, Vahlia $M$ and Vanage G (2013) Efficacy and safety of a herbomineral ayurvedic formulation 'Afrodet Plus((R))' in male rats J Ayurveda Integr Med 4 158-164

Dongre S, Langade D and Bhattacharyya S (2015) Efficacy and safety of ashwagandha (Withania somnifera) root extract in improving sexual function in women: a pilot study Biomed Res Int 2015

Elangovan P, Jalaludeen A M, Ramakrishnan R and Pari L (2016) Protective Effect of Troxerutin on Nickel-Induced Testicular Toxicity in Wistar Rats J Environ Pathol Toxicol Oncol 35133-46

Gandhi G R, Ignacimuthu S and Paulraj M G (2012) Hypoglycemic and beta-cells regenerative effects of Aegle marmelos (L.) Corr. bark extract in streptozotocin-induced diabetic rats Food Chem Toxicol 50 1667-1674

Gandhi G R, Stalin A, Balakrishna K, Ignacimuthu S, Paulraj M $G$ and Vishal R (2013) Insulin sensitization via partial agonism of PPARgamma and glucose uptake through translocation and activation of GLUT4 in PI3K/p-Akt signaling pathway by embelin in type 2 diabetic rats Biochim Biophys Acta1830 2243-2255

Gandhi G R, Vanlalhruaia P, Stalin A, Irudayaraj S S, Ignacimuthu S and Paulraj M G (2014) Polyphenols-rich Cyamopsis tetragonoloba (L.) Taub. beans show hypoglycemic and beta-cells protective effects in type 2 diabetic rats Food Chem Toxicol 66 358-365

Garabadu D and Krishnamurthy S (2014) Diazepam potentiates the antidiabetic, antistress and anxiolytic activities of metformin in type- 2 diabetes mellitus with cooccurring stress in experimental animals Biomed Res Int 2014693074

Garabadu D and Krishnamurthy S (2014) Asparagus racemosus attenuates anxiety-like behavior in experimental animal models Cell Mol Neurobiol 34 511-521

Gautam S, Pal S, Maurya R and Srivastava A K (2015) Ethanolic extract of Allium cepa stimulates glucose transporter typ 4-mediated glucose uptake by the activation of insulin signaling Planta Med 81 208-214

Gautam S, Ishrat N, Singh R, Narender T and Srivastava A K (2015) Aegeline from Aegle marmelos stimulates glucose transport via Akt and Rac1 signaling, and contributes to a cytoskeletal rearrangement through PI3K/Rac1 Eur $J$ Pharmacol 762 419-429

Ghosh A, Jana K, Pakhira B P and Ghosh D (2016) Antiapoptotic efficacy of seed of Eugenia jambolana on testicular germ cell in experimental diabetic rat: a genomic study Andrologia 48 282-292

Ghosh A, Jana K, Ali K M, De D, Chatterjee K and Ghosh D (2014) Corrective role of Eugenia jambolana on testicular impairment in streptozotocin-induced diabetic male albino rat: an approach through genomic and proteomic study 
Andrologia 46 296-307

Goel A, Nag P, Rahuja N, Srivastava R, Chaurasia S, Gautam S, Chandra S, Siddiqi M I and Srivastava A K (2014) Discovery of biaryl-4-carbonitriles as antihyperglycemic agents that may act through AMPK-p38 MAPK pathway Mol Cell Endocrinol 394 1-12

Gopal S S, Lakshmi M J, Sharavana G, Sathaiah G, Sreerama Y N and Baskaran V (2017) Lactucaxanthin - a potential antidiabetic carotenoid from lettuce (Lactuca sativa) inhibits alpha-amylase and alpha-glucosidase activity in vitro and in diabetic rats Food Funct 8 1124-1131

Gopalakrishna Pillai G K, Bharate S S, Awasthi A, Verma R, Mishra G, Singh A T, Jaggi M, Mithal A and Vishwakarma R A (2017) Antidiabetic potential of polyherbal formulation DB14201: Preclinical development, safety and efficacy studies J Ethnopharmacol 197 218-230

Govindaraj J and Sorimuthu Pillai S (2015) Rosmarinic acid modulates the antioxidant status and protects pancreatic tissues from glucolipotoxicity mediated oxidative stress in high-fat diet: streptozotocin-induced diabetic rats $\mathrm{Mol} \mathrm{Cell}$ Biochem 404 143-159

Gowda N, Dandu A, Singh J, Biswas S, Raghav V, Lakshmi M N, Shilpa P C, Sunil V, Reddy A, Sadasivuni M, Aparna K, Verma M K, Moolemath Y, Anup M O, Venkataranganna M V, Somesh B P and Jagannath M R (2013) Treatment with CNX-011-67, a novel GPR40 agonist, delays onset and progression of diabetes and improves beta cell preservation and function in male ZDF rats $B M C$ Pharmacol Toxicol $\mathbf{1 4} 28$

Gujjala S, Putakala M, Gangarapu V, Nukala S, Bellamkonda R, Ramaswamy R and Desireddy S (2016) Protective effect of Caralluma fimbriata against high-fat diet induced testicular oxidative stress in rats Biomed Pharmacother 83 167-176

Gupta D, Radhakrishnan M and Kurhe Y (2014) 5HT3 receptor antagonist (ondansetron) reverses depressive behavior evoked by chronic unpredictable stress in mice: modulation of hypothalamic-pituitary-adrenocortical and brain serotonergic system Pharmacol Biochem Behav 124 129136

Gupta H, Maheshwari K K and Kumar N (2013) Reversible germ cell toxicity of sulphasalazine and ampicillin combination in male rats J Reprod Infertil 14 126-132

Gupta N, Chakrabarti K, Prakash K, Wadhwa N, Gupta T and Gupta S K (2013) Immunogenicity and contraceptive efficacy of Escherichia coli-expressed recombinant porcine zona pellucida proteins Am J Reprod Immunol 70 139152
Gupta R, Kachhawa J B S, Gupta R S, Sharma A K, Sharma M C and Dobhal M P (2011) Phytochemical evaluation and antispermatogenic activity of Thevetia peruviana methanol extract in male albino rats Hum Fertil 14 53-59

Gupta S K, Dongare S, Mathur R, Mohanty I R, Srivastava S, Mathur S and Nag T C (2015) Genistein ameliorates cardiac inflammation and oxidative stress in streptozotocininduced diabetic cardiomyopathy in rats $\mathrm{Mol} \mathrm{Cell} \mathrm{Biochem}$ 408 63-72

Guvvala P R, Sellappan S and Parameswaraiah R J (2016) Impact of arsenic (V) on testicular oxidative stress and sperm functional attributes in Swiss albino mice Environ Sci Pollut Res Int 23 18200-18210

Hardikar M R, Varma M E, Kulkarni A A, Kulkarni P P and Joshi B N (2016) Elucidation of hypoglycemic action and toxicity studies of insulin-like protein from Costus igneus Phytochemistry 124 99-107

IDF (2015) International Diabetes Federation Diabetes Atlas 7th edition [online] http://www.idf.org/

Irudayaraj S S, Stalin A, Sunil C, Duraipandiyan V, Al-Dhabi N A and Ignacimuthu S (2016) Antioxidant, antilipidemic and antidiabetic effects of ficusin with their effects on GLUT4 translocation and PPARgamma expression in type 2 diabetic rats Chem Biol Interact 256 85-93

Jain M R, Giri S R, Trivedi C, Bhoi B, Rath A, Vanage G, Vyas P, Ranvir R and Patel P R (2015) Saroglitazar, a novel PPARalpha/gamma agonist with predominant PPARalpha activity, shows lipid-lowering and insulin-sensitizing effects in preclinical models Pharmacol Res Perspect 3 e00136

Jain M R, Joharapurkar A A, Bahekar R H, Patel H, Jadav P, Kshirsagar S G, Patel V J, Patel K N, Ramanathan V K, Patel P R and Desai R C (2015) Pharmacological characterization of ZYDPLA1, a novel long-acting dipeptidyl peptidase-4 inhibitor J Diabetes 7 708-717

Jain S, Rathi V V, Jain A K, Das M and Godugu C (2012) Folatedecorated PLGA nanoparticles as a rationally designed vehicle for the oral delivery of insulin Nanomedicine (Lond) 7 1311-1337

Jangra A, Datusalia A K, Khandwe S and Sharma S S (2013) Amelioration of diabetes-induced neurobehavioral and neurochemical changes by melatonin and nicotinamide: implication of oxidative stress-PARP pathway Pharmacol Biochem Behav 114-115 43-51

Jawale A, Datusalia A K, Bishnoi M and Sharma S S (2016) Reversal of diabetes-induced behavioral and neurochemical deficits by cinnamaldehyde Phytomedicine 23 923-930

Jayanarayanan S, Anju T R, Smijin S and Paulose C S (2015) 
Vitamin D3 supplementation increases insulin level by regulating altered IP3 and AMPA receptor expression in the pancreatic islets of streptozotocin-induced diabetic rat J Nutr Biochem 26 1041-1049

Jayanthy G, Roshana Devi V, Ilango K and Subramanian S P (2017) Rosmarinic Acid Mediates Mitochondrial Biogenesis in Insulin Resistant Skeletal Muscle Through Activation of AMPK J Cell Biochem 118 1839-1848

Jena A K, Vasisht K, Sharma N, Kaur R, Dhingra M S and Karan M (2016) Amelioration of testosterone induced benign prostatic hyperplasia by Prunus species J Ethnopharmacol $19033-45$

Joshi B N, Munot H, Hardikar M and Kulkarni A A (2013) Orally active hypoglycemic protein from Costus igneus N. E. Br.: an in vitro and in vivo study Biochem Biophys Res Commun 436 278-282

Joshi R P, Negi G, Kumar A, Pawar Y B, Munjal B, Bansal A K and Sharma S S (2013) SNEDDS curcumin formulation leads to enhanced protection from pain and functional deficits associated with diabetic neuropathy: an insight into its mechanism for neuroprotection Nanomedicine 9 776-785

Joshi S, Nair N and Bedwal R S (2014) Dietary zinc deficiency effects dorso-lateral and ventral prostate of Wistar rats: histological, biochemical and trace element study Biol Trace Elem Res 161 91-100

Joy K P, Singh V and Chaube R (2014) An in vitro study on catecholamine modulation of ovarian steroidogenic activity in the catfish Heteropneustes fossilis Gen Comp Endocrinol 196 91-99

Kadakol A, Pandey A, Goru S K, Malek V and Gaikwad A B (2015) Insulin sensitizing and cardioprotective effects of Esculetin and Telmisartan combination by attenuating Ang II mediated vascular reactivity and cardiac fibrosis Eur J Pharmacol 765 591-597

Kadakol A, Malek V, Goru S K, Pandey A, Bagal S and Gaikwad A B (2015) Esculetin attenuates alterations in Ang II and acetylcholine mediated vascular reactivity associated with hyperinsulinemia and hyperglycemia Biochem Biophys Res Commun 461 342-347

Kala M and Nivsarkar M (2016) Role of cortisol and superoxide dismutase in psychological stress induced anovulation Gen Comp Endocrinol 225 117-124

Kalra S, Bantwal G and John M (2012) The exaptation of endocrine pharmacology Indian J Endocrinol Metab 16 329-330

Kanchan D M, Somani G S, Peshattiwar V V, Kaikini A A and Sathaye S (2016) Renoprotective effect of diosgenin in streptozotocin induced diabetic rats Pharmacol Rep 68 370-377

Kanimozhi V, Palanivel K, Kadalmani B, Krikun G and Taylor H S (2014) Apolipoprotein E induction in Syrian hamster testis following tributyltin exposure: a potential mechanism of male infertility Reprod Sci 21 1006-1014

Katare P B and Banerjee S K (2016) Repositioning of Drugs in Cardiometabolic Disorders: Importance and Current Scenario Curr Top Med Chem 16 2189-2200

Kaur G, Padiya R, Adela R, Putcha U K, Reddy G S, Reddy B R, Kumar K P, Chakravarty S and Banerjee S K (2016) Garlic and Resveratrol Attenuate Diabetic Complications, Loss of beta-Cells, Pancreatic and Hepatic Oxidative Stress in Streptozotocin-Induced Diabetic Rats Front Pharmacol 7 360

Khan M P, Mishra J S, Sharan K, Yadav M, Singh A K, Srivastava A, Kumar S, Bhaduaria S, Maurya R, Sanyal S and Chattopadhyay N (2013) A novel flavonoid C-glucoside from Ulmus wallichiana preserves bone mineral density, microarchitecture and biomechanical properties in the presence of glucocorticoid by promoting osteoblast survival: a comparative study with human parathyroid hormone Phytomedicine 20 1256-1266

Khan S and Jena G B (2014) Protective role of sodium butyrate, a HDAC inhibitor on beta-cell proliferation, function and glucose homeostasis through modulation of p38/ERK MAPK and apoptotic pathways: study in juvenile diabetic rat Chem Biol Interact 213 1-12

Khan S and Jena G (2016) Sodium butyrate reduces insulinresistance, fat accumulation and dyslipidemia in type- 2 diabetic rat: A comparative study with metformin Chem Biol Interact 254 124-134

Khan S and Jena G (2016) Valproic Acid Improves Glucose Homeostasis by Increasing Beta-Cell Proliferation, Function, and Reducing its Apoptosis through HDAC Inhibition in Juvenile Diabetic Rat J Biochem Mol Toxicol $30438-446$

Khan S, Jena G and Tikoo K (2015) Sodium valproate ameliorates diabetes-induced fibrosis and renal damage by the inhibition of histone deacetylases in diabetic rat Exp Mol Pathol 98 230-239

Khan S, Adhikari J S, Rizvi M A and Chaudhury N K (2015) Radioprotective potential of melatonin against $(6)(0) \mathrm{Co}$ gamma-ray-induced testicular injury in male C57BL/6 mice J Biomed Sci 2261

Khan S, Adhikari J S, Rizvi M A and Chaudhury N K (2017) Melatonin attenuates 60 Co gamma-ray-induced hematopoietic, immunological and gastrointestinal injuries 
in C57BL/6 male mice Environ Toxicol 32 501-518

Khanra R, Bhattacharjee N, Dua T K, Nandy A, Saha A, Kalita J, Manna P and Dewanjee S (2017) Taraxerol, a pentacyclic triterpenoid, from Abroma augusta leaf attenuates diabetic nephropathy in type 2 diabetic rats Biomed Pharmacother 94 726-741

Kharatmal S B, Singh J N and Sharma S S (2015) Calpain inhibitor, MDL 28170 confer electrophysiological, nociceptive and biochemical improvement in diabetic neuropathy Neuropharmacology 97 113-121

Kharatmal S B, Singh J N and Sharma S S (2015) Rufinamide Improves Functional and Behavioral Deficits via Blockade of Tetrodotoxin-Resistant Sodium Channels in Diabetic Neuropathy Curr Neurovasc Res 12 262-268

Khare P, Datusalia A K and Sharma S S (2017) Parthenolide, an NF-kappaB Inhibitor Ameliorates Diabetes-Induced Behavioural Deficit, Neurotransmitter Imbalance and Neuroinflammation in Type 2 Diabetes Rat Model Neuromolecular Med 19 101-112

Kokilavani P, Suriyakalaa U, Elumalai P, Abirami B, Ramachandran R, Sankarganesh A and Achiraman S (2014) Antioxidant mediated ameliorative steroidogenesis by Commelina benghalensis L. and Cissus quadrangularis L. against quinalphos induced male reproductive toxicity Pestic Biochem Physiol 109 18-33

Kumar A and Bharti S K (2017) Therapeutic molecules against type 2 diabetes: What we have and what are we expecting? Pharmacol Rep 69 959-970

Kumar A, Begum N, Prasad S, Aggarwal S and Sharma S (2014) Oral dydrogesterone treatment during early pregnancy to prevent recurrent pregnancy loss and its role in modulation of cytokine production: a double-blind, randomized, parallel, placebo-controlled trial Fertil Steril 102 13571363. e1353

Kumar G S, Kulkarni A, Khurana A, Kaur J and Tikoo K (2014) Selenium nanoparticles involve HSP-70 and SIRT1 in preventing the progression of type 1 diabetic nephropathy Chem Biol Interact 223 125-133

Kumar K M, Aruldhas M M, Banu S L, Sadasivam B, Vengatesh G, Ganesh K M, Navaneethabalakrishnan S, Navin A K, Michael F M and Venkatachalam S (2017) Male reproductive toxicity of CrVI: In-utero exposure to CrVI at the critical window of testis differentiation represses the expression of Sertoli cell tight junction proteins and hormone receptors in adult $\mathrm{F} 1$ progeny rats Reprod Toxicol 69 84-98

Kumar N, Srivastava S and Roy P (2015) Impact of low molecular weight phthalates in inducing reproductive malfunctions in male mice: Special emphasis on Sertoli cell functions Gen Comp Endocrinol 215 36-50

Kumar S and Kaur G (2014) Second generation anti-epileptic drugs adversely affect reproductive functions in young non-epileptic female rats Eur Neuropsychopharmacol 24 1709-1718

Kumari M and Singh P (2013) Study on the reproductive organs and fertility of the male mice following administration of metronidazole Int J Fertil Steril 7225

Lonare M, Kumar M, Raut S, More A, Doltade S, Badgujar P and Telang A (2016) Evaluation of ameliorative effect of curcumin on imidacloprid-induced male reproductive toxicity in wistar rats Environ Toxicol 31 1250-1263

Londonkar R L and Nayaka H B (2013) Effect of ethanol extract of Portulaca oleracea $\mathrm{L}$ on ovulation and estrous cycle in female albino rats Journal of pharmacy research 6 431436

Madhu P, Reddy K P and Reddy P S (2015) Melatonin reduces oxidative stress and restores mitochondrial function in the liver of rats exposed to chemotherapeutics J Exp Zool A Ecol Genet Physiol 323 301-308

Mahapatra D and Chandra A K (2017) Biphasic action of iodine in excess at different doses on ovary in adult rats $J$ Trace Elem Med Biol 39 210-220

Maheshwari A, Verma N, Swaroop A, Bagchi M, Preuss H G, Tiwari K and Bagchi D (2017) Efficacy of FurosapTM, a novel Trigonella foenum-graecum seed extract, in Enhancing Testosterone Level and Improving Sperm Profile in Male Volunteers Int J Med Sci 1458

Maremanda K P, Khan S and Jena G (2014) Zinc protects cyclophosphamide-induced testicular damage in rat: involvement of metallothionein, tesmin and Nrf2 Biochem Biophys Res Commun 445 591-596

Maremanda K P, Khan S and Jena G B (2016) Role of Zinc Supplementation in Testicular and Epididymal Damages in Diabetic Rat: Involvement of Nrf2, SOD1, and GPX5 Biol Trace Elem Res 173 452-464

Meena R, Kajal K and Paulraj R (2015) Cytotoxic and genotoxic effects of titanium dioxide nanoparticles in testicular cells of male wistar ratAppl Biochem Biotechnol 175 825-840

Meena R, Kumari K, Kumar J, Rajamani P, Verma H N and Kesari K K (2014) Therapeutic approaches of melatonin in microwave radiations-induced oxidative stress-mediated toxicity on male fertility pattern of Wistar rats Electromagn Biol Med 33 81-91

Mehta K D, Mehta A K, Halder S, Khanna N, Tripathi A K and Sharma K K (2014) Protective effect of melatonin on propoxur-induced impairment of memory and oxidative 
stress in rats Environ Toxicol 29 705-713

Mishra M, Mishra V, Chaudhuri B P, Khanna V K, Mehrotra S, Ali S and Das M (2013) Anomalies in ovary following oral exposure to oxytocin: mechanistic studies Reprod Toxicol 40 24-34

Mishra R K and Singh S K (2016) Biphasic effect of Syzygium aromaticum flower bud on reproductive physiology of male mice Andrologia 48 1011-1020

Moniruzzaman M, Hasan K N and Maitra S K (2016) Melatonin actions on ovaprim (synthetic GnRH and domperidone)induced oocyte maturation in carp Reproduction 151285 296

Mukherjee A and Haldar C (2015) Effect of Naltrexone on photoperiodic regulation of testicular steroidogenesis in adult golden hamster, Mesocricetus auratus Gen Comp Endocrinol 239 89-96

Mukherjee A, Haldar C and Vishwas D K (2015) Melatonin prevents dexamethasone-induced testicular oxidative stress and germ cell apoptosis in golden hamster, Mesocricetus auratus Andrologia 47 920-931

Mukherjee D, Ghosh A K, Bandyopadhyay A, Basu A, Datta S, Pattari S K, Reiter R J and Bandyopadhyay D (2012) Melatonin protects against isoproterenol-induced alterations in cardiac mitochondrial energy-metabolizing enzymes, apoptotic proteins, and assists in complete recovery from myocardial injury in rats $J$ Pineal Res $\mathbf{5 3}$ 166-179

Naim M J, Alam M J, Nawaz F, Naidu V G M, Aaghaz S, Sahu M, Siddiqui N and Alam O (2017) Synthesis, molecular docking and anti-diabetic evaluation of 2,4thiazolidinedione based amide derivatives Bioorg Chem 73 24-36

Narayanan D, Anitha A, Jayakumar R and Chennazhi K P(2013) In vitro and in vivo evaluation of osteoporosis therapeutic peptide PTH 1-34 loaded pegylated chitosan nanoparticles Mol Pharm $104159-4167$

Narayanan D, Anitha A, Jayakumar R and Chennazhi K P (2014) PTH 1-34 loaded thiolated chitosan nanoparticles for osteoporosis: oral bioavailability and anabolic effect on primary osteoblast cells J Biomed Nanotechnol 10 166178

Neerati P, Devde R and Gangi A K (2014) Evaluation of the effect of curcumin capsules on glyburide therapy in patients with type-2 diabetes mellitus Phytother Res 28 1796-1800

Ojo O O, Bhadauria S and Rath S K (2013) Dose-dependent adverse effects of salinomycin on male reproductive organs and fertility in mice PloS one $\mathbf{8}$ e69086
Pai S A and Majumdar A S (2014) Protective effects of melatonin against metabolic and reproductive disturbances in polycystic ovary syndrome in rats $J$ Pharm Pharmacol 66 1710-1721

Panda S and Kar A (2014) Antithyroid effects of naringin, hesperidin and rutin in 1-T4 induced hyperthyroid rats: possible mediation through 5'DI activity Pharmacol Rep 66 1092-1099

Panda S and Kar A (2015) Protective effects of 5,7,4'-trihydroxy6,3'dimethoxy-flavone 5-O-alpha-1-rhamnopyranoside, isolated from Annona squamosa leaves in thyrotoxicosis and in hepatic lipid peroxidation in rats Bioorg Med Chem Lett 25 5726-5728

Panda S and Kar A (2016) Role of a gitogenin-type steroidal saponin (3-O-beta-d-glucopyranosyl $(1 \longrightarrow 2)$-beta-dglucopyranosyl (1->4)-beta-d-galactopyranoside25R,5alpha-spirostane-2alpha,3beta-diol), isolated from the leaves of Malvastrum coromandelianum in regulating thyrotoxicosis in rats Bioorg Med Chem Lett 26 48044807

Pandey A K, Ghuman S P, Dhaliwal G S, Kumar A and Agarwal S K (2013) Impact of buserelin acetate or hCG administration on day 12 post-ovulation on subsequent luteal profile and conception rate in buffalo (Bubalus bubalis) Anim Reprod Sci 136 260-267

Pandey S P, Singh H K and Prasad S (2015) Alterations in Hippocampal Oxidative Stress, Expression of AMPA Receptor GluR2 Subunit and Associated Spatial Memory Loss by Bacopa monnieri Extract (CDRI-08) in Streptozotocin-Induced Diabetes Mellitus Type 2 Mice PLoS One $\mathbf{1 0} \mathrm{e} 0131862$

Pandey S P, Tsutsui K and Mohanty B (2017) Endocrine disrupting pesticides impair the neuroendocrine regulation of reproductive behaviors and secondary sexual characters of red munia (Amandava amandava) Physiol Behav 173 $15-22$

Pant N, Kumar G, Upadhyay A D, Patel D K, Gupta Y K and Chaturvedi P K (2014) Reproductive toxicity of lead, cadmium, and phthalate exposure in men Environ Sci Pollut Res Int 21 11066-11074

Pari L and Chandramohan R (2017) Modulatory effects of naringin on hepatic key enzymes of carbohydrate metabolism in high-fat diet/low-dose streptozotocin-induced diabetes in rats Gen Physiol Biophys 36 343-352

Patel O P, Mishra A, Maurya R, Saini D, Pandey J, Taneja I, Raju K S, Kanojiya S, Shukla S K, Srivastava M N, Wahajuddin M, Tamrakar A K, Srivastava A K and Yadav P P (2016) Naturally Occurring Carbazole Alkaloids from Murraya 
koenigii as Potential Antidiabetic Agents J Nat Prod 79 1276-1284

Paudel Y N, Ali M R, Shah S, Adil M, Akhtar M S, Wadhwa R, Bawa S and Sharma M (2017) 2-[(4-Chlorobenzyl) amino]4-methyl-1,3-thiazole-5-carboxylic acid exhibits antidiabetic potential and raises insulin sensitivity via amelioration of oxidative enzymes and inflammatory cytokines in streptozotocin-induced diabetic rats Biomed Pharmacother 89 651-659

Prasad S N, Bharath M M and Muralidhara (2016) Neurorestorative effects of eugenol, a spice bioactive: Evidence in cell model and its efficacy as an intervention molecule to abrogate brain oxidative dysfunctions in the streptozotocin diabetic rat Neurochem Int 95 24-36

Prasath G S and Subramanian S P (2013) Fisetin, a tetra hydroxy flavone recuperates antioxidant status and protects hepatocellular ultrastructure from hyperglycemia mediated oxidative stress in streptozotocin induced experimental diabetes in rats Food Chem Toxicol 59 249-255

Prasath G S and Subramanian S P (2014) Antihyperlipidemic effect of fisetin, a bioflavonoid of strawberries, studied in streptozotocin-induced diabetic rats J Biochem Mol Toxicol 28 442-449

Prasath G S, Sundaram C S and Subramanian S P (2013) Fisetin averts oxidative stress in pancreatic tissues of streptozotocin-induced diabetic rats Endocrine 44 359368

Prasath G S, Pillai S I and Subramanian S P (2014) Fisetin improves glucose homeostasis through the inhibition of gluconeogenic enzymes in hepatic tissues of streptozotocin induced diabetic rats Eur J Pharmacol 740 248-254

Raghu G, Jakhotia S, Yadagiri Reddy P, Kumar P A and Bhanuprakash Reddy G (2016) Ellagic acid inhibits nonenzymatic glycation and prevents proteinuria in diabetic rats Food Funct 7 1574-1583

Rajput M S and Sarkar P D (2017) Modulation of neuroinflammatory condition, acetylcholinesterase and antioxidant levels by genistein attenuates diabetes associated cognitive decline in mice Chem Biol Interact 268 93-102

Ramakrishnan S (2015) From 'Make in India' to 'Made in India': the saroglitazar story Indian Heart J 67 8-10

Rani N, Bharti S, Bhatia J, Nag T C, Ray R and Arya D S (2016) Chrysin, a PPAR-gamma agonist improves myocardial injury in diabetic rats through inhibiting AGE-RAGE mediated oxidative stress and inflammation Chem Biol Interact 250 59-67

Rani R, Dahiya S, Dhingra D, Dilbaghi N, Kim K H and Kumar S
(2017) Evaluation of anti-diabetic activity of glycyrrhizinloaded nanoparticles in nicotinamide-streptozotocininduced diabetic rats Eur J Pharm Sci 106 220-230

Rao G, Verma R, Mukherjee A, Haldar C and Agrawal N K (2016) Melatonin alleviates hyperthyroidism induced oxidative stress and neuronal cell death in hippocampus of aged female golden hamster, Mesocricetus auratus Exp Gerontol 82 125-130

Rather M A, Sharma R, Gupta S, Ferosekhan S, Ramya V L and Jadhao S B (2013) Chitosan-nanoconjugated hormone nanoparticles for sustained surge of gonadotropins and enhanced reproductive output in female fish PloS one $\mathbf{8}$ e57094

Rathinam A and Pari L (2016) Myrtenal ameliorates hyperglycemia by enhancing GLUT2 through Akt in the skeletal muscle and liver of diabetic rats Chem Biol Interact 256 161-166

Roy V K, Chenkual L and Gurusubramanian G (2015) Protection of testis through antioxidant action of Mallotus roxburghianus in alloxan-induced diabetic rat model $J$ Ethnopharmacol 176 268-280

Roychoudhury S, Nath S, Massanyi P, Stawarz R, Kacaniova M and Kolesarova A (2016) Copper-induced changes in reproductive functions: in vivo and in vitro effects $P$ hysiol Res 6511

Rungsung S, Khan A M, Sood N K, Rampal S and Saini S P S (2016) Evaluation of ameliorative potential of supranutritional selenium on enrofloxacin-induced testicular toxicity Chem Biol Interact 252 87-92

Saha P, Saraswat G, Chakraborty P, Banerjee S, Pal B C and Kabir S N (2012) Puerarin, a selective oestrogen receptor modulator, disrupts pregnancy in rats at pre-implantation stage Reproduction 144 633-645

Samanta J, Bhattacharya S and Rana A C (2016) Antifertility activity of Thevetia peruviana (Pers.) K. Schum leaf in female Sprague-Dawley rat Indian J Pharmacol 48669

Samuel J B, Stanley J A, Sekar P, Princess R A, Sebastian M S and Aruldhas M M (2014) Persistent hexavalent chromium exposure impaired the pubertal development and ovarian histoarchitecture in wistar rat offspring Environ Toxicol 29 814-828

Sandireddy R, Yerra V G, Komirishetti P, Areti A and Kumar A (2016) Fisetin Imparts Neuroprotection in Experimental Diabetic Neuropathy by Modulating Nrf2 and NF-kappaB Pathways Cell Mol Neurobiol 36 883-892

Saraswat G, Guha R, Mondal K, Saha P, Banerjee S, Chakraborty P, Konar A and Kabir S N (2016) Molecular cues to the anti-implantation effect of nano-puerarin in rats 
Reproduction 151 693-707

Sarkar D, Chowdhury J P and Singh S K (2016) Effect of polybrominated diphenyl ether (BDE-209) on testicular steroidogenesis and spermatogenesis through altered thyroid status in adult mice Gen Comp Endocrinol 239 50-61

Sarkar S, Mukherjee A, Das N and Swarnakar S (2017) Protective roles of nanomelatonin in cerebral ischemia-reperfusion of aged brain: Matrixmetalloproteinases as regulators $\operatorname{Exp}$ Gerontol 92 13-22

Saxena P, Gupta R and Gupta R S (2015) Contraceptive studies of isolated fractions of Cuminum cyminum in male albino rats Nat Prod Res 29 2328-2331

Sekaran S, Balaganapathy P, Parsanathan R, Elangovan S, Gunashekar J, Bhat FA and Jagadeesan A (2015) Lactational exposure of phthalate causes long-term disruption in testicular architecture by altering tight junctional and apoptotic protein expression in Sertoli cells of first filial generation pubertal Wistar rats Hum Exp Toxicol 34 575590

Selvaraj J, Sathish S, Mayilvanan C and Balasubramanian K (2013) Excess aldosterone-induced changes in insulin signaling molecules and glucose oxidation in gastrocnemius muscle of adult male rat Mol Cell Biochem 372 113-126

Sendrayaperumal V, Iyyam Pillai S and Subramanian S (2014) Design, synthesis and characterization of zinc-morin, a metal flavonol complex and evaluation of its antidiabetic potential in HFD-STZ induced type 2 diabetes in rats Chem Biol Interact 219 9-17

Shaik A, Kanhere R S, Cuddapah R, Nelson K S, Vara P R and Sibyala S (2014) Antifertility activity of Artemisia vulgaris leaves on female Wistar rats Chin J Nat Med 12 180-185

Shaikh M V, Kala M, Ravat N and Nivsarkar M (2015) Abortifacient potential of methanolic extract of Anthocephalus cadamba stem bark in mice $J$ Ethnopharmacol 173 313-317

Shakya A, Soni U K, Rai G, Chatterjee S S and Kumar V (2016) Gastro-protective and Anti-stress Efficacies of Monomethyl Fumarate and a Fumaria indica Extract in Chronically Stressed Rats Cell Mol Neurobiol 36 621-635

Sharma A K, Bharti S, Kumar R, Krishnamurthy B, Bhatia J, Kumari S and Arya D S (2012) Syzygium cumini ameliorates insulin resistance and beta-cell dysfunction via modulation of PPAR, dyslipidemia, oxidative stress, and TNF-alpha in type 2 diabetic rats $J$ Pharmacol Sci 119 205-213

Sharma D, Bhattacharya P, Kalia K and Tiwari V (2017) Diabetic nephropathy: New insights into established therapeutic paradigms and novel molecular targets Diabetes Res Clin
Pract 128 91-108

Sharma P, Huq A U and Singh R (2013) Cypermethrin induced reproductive toxicity in male Wistar rats: Protective role of Tribulus terrestris J Environ Biol 34 857-62

Sharma P, Singh R and Jan M (2014) Dose-dependent effect of deltamethrin in testis, liver, and Kidney of wistar rats Toxicol Int 21 131-39

Sharma P, Huq A U and Singh R (2014) Cypermethrin-induced reproductive toxicity in the rat is prevented by resveratrol J Hum Reprod Sci 7 99-106

Sharma R, Gupta U, Garg N K, Tyagi R K and Jain N K (2015) Surface engineered and ligand anchored nanobioconjugate: an effective therapeutic approach for oral insulin delivery in experimental diabetic rats Colloids Surf B Biointerfaces 127 172-181

Sharma V, Boonen J, Spiegeleer B D and Dixit V K (2013) Androgenic and Spermatogenic Activity of Alkylamide Rich Ethanol Solution Extract of Anacyclus pyrethrum DC Phytother Res 27 99-106

Shukla A and Srinivasan B P (2012) 16,17-Dihydro-17b-hydroxy isomitraphylline alkaloid as an inhibitor of DPP-IV, and its effect on incretin hormone and beta-cell proliferation in diabetic rat Eur J Pharm Sci 47 512-519

Singh A, Suragani M and Krishna A (2014) Effects of resistin on ovarian folliculogenesis and steroidogenesis in the vespertilionid bat, Scotophilus heathi Gen Comp Endocrinol 208 73-84

Singh A, Arvinda S, Singh S, Suri J, Koul S, Mondhe D M, Singh G and Vishwakarma R (2017) IN0523 (Urs-12-ene3alpha,24beta-diol) a plant based derivative of boswellic acid protect Cisplatin induced urogenital toxicity Toxicol Appl Pharmacol 318 8-15

Singh J, Chaudhari B P and Kakkar P (2017) Baicalin and chrysin mixture imparts cyto-protection against methylglyoxal induced cytotoxicity and diabetic tubular injury by modulating RAGE, oxidative stress and inflammation Environ Toxicol Pharmacol 50 67-75

Singh K, Dubey B K, Tripathi A C, Singh A P and Saraf S K (2014) Natural male contraceptive: phytochemical investigation and anti-spermatogenic activity of Pistia stratiotes Linn Nat Prod Res 28 1313-1317

Singh N and Singh S K (2016) Citrus limon extract: possible inhibitory mechanisms affecting testicular functions and fertility in male mice Syst Biol Reprod Med 62 39-48

Singh P, Srivastava R K and Krishna A (2016) Effects of gonadotropin-releasing hormone agonist and antagonist on ovarian activity in a mouse model for polycystic ovary $J$ Steroid Biochem Mol Biol 163 35-44 
Singh P, Jayaramaiah R H, Agawane S B, Vannuruswamy G, Korwar A M, Anand A, Dhaygude V S, Shaikh M L, Joshi R S, Boppana R, Kulkarni M J, Thulasiram H V and Giri A P (2016) Potential Dual Role of Eugenol in Inhibiting Advanced Glycation End Products in Diabetes: Proteomic and Mechanistic Insights Sci Rep 618798

Sireesh D, Ganesh M R, Dhamodharan U, Sakthivadivel M, Sivasubramanian S, Gunasekaran P and Ramkumar K M (2017) Role of pterostilbene in attenuating immune mediated devastation of pancreatic beta cells via Nrf2 signaling cascade J Nutr Biochem 44 11-21

Sm S and Mahaboob Basha P(2017) Fluoride Exposure Aggravates the Testicular Damage and Sperm Quality in Diabetic Mice: Protective Role of Ginseng and Banaba Biol Trace Elem Res 177 331-344

Sole S S and Srinivasan B P (2012) Aqueous extract of tamarind seeds selectively increases glucose transporter-2, glucose transporter-4, and islets' intracellular calcium levels and stimulates beta-cell proliferation resulting in improved glucose homeostasis in rats with streptozotocin-induced diabetes mellitus Nutr Res 32 626-636

Sole S S, Srinivasan B P and Akarte A S (2013) Anti-inflammatory action of Tamarind seeds reduces hyperglycemic excursion by repressing pancreatic beta-cell damage and normalizing SREBP-1c concentration Pharm Biol 51 350-360

Srinivasan K and Sharma S S (2012) 3-Bromo-7-nitroindazole attenuates brain ischemic injury in diabetic stroke via inhibition of endoplasmic reticulum stress pathway involving CHOP Life Sci 90 154-160

Stalin A, Irudayaraj S S, Gandhi G R, Balakrishna K, Ignacimuthu S and Al-Dhabi N A (2016) Hypoglycemic activity of 6bromoembelin and vilangin in high-fat diet fedstreptozotocin-induced type 2 diabetic rats and molecular docking studies Life Sci 153 100-117

Stephen Irudayaraj S, Christudas S, Antony S, Duraipandiyan V, Naif Abdullah A D and Ignacimuthu S (2017) Protective effects of Ficus carica leaves on glucose and lipids levels, carbohydrate metabolism enzymes and beta-cells in type 2 diabetic rats Pharm Biol 55 1074-1081

Subhasree N, Kamella A, Kaliappan I, Agrawal A and Dubey G P (2015) Antidiabetic and antihyperlipidemic activities of a novel polyherbal formulation in high fat diet/ streptozotocin induced diabetic rat model Indian $J$ Pharmacol 47 509-513

Sultana M R, Bagul P K, Katare P B, Anwar Mohammed S, Padiya R and Banerjee S K (2016) Garlic activates SIRT-3 to prevent cardiac oxidative stress and mitochondrial dysfunction in diabetes Life Sci 164 42-51
Sundaram B, Singhal K and Sandhir R (2012) Ameliorating effect of chromium administration on hepatic glucose metabolism in streptozotocin-induced experimental diabetes Biofactors 38 59-68

Sundaram B, Aggarwal A and Sandhir R (2013) Chromium picolinate attenuates hyperglycemia-induced oxidative stress in streptozotocin-induced diabetic rats J Trace Elem Med Biol 27 117-121

Sunil V, Verma M K, Oommen A M, Sadasivuni M, Singh J, Vijayraghav D N, Chandravanshi B, Shetty J, Biswas S, Dandu A, Moolemath Y, Venkataranganna M V, Somesh B P and Jagannath M R (2014) CNX-011-67, a novel GPR40 agonist, enhances glucose responsiveness, insulin secretion and islet insulin content in $\mathrm{n}-\mathrm{STZ}$ rats and in islets from type 2 diabetic patients BMC Pharmacol Toxicol 1519

Suresh S and Prakash S (2012) Effect of Mucuna pruriens (Linn.) on sexual behavior and sperm parameters in streptozotocininduced diabetic male rat $J$ Sex Med 9 3066-3078

Swaroop A, Jaipuriar A S, Gupta S K, Bagchi M, Kumar P, Preuss H G and Bagchi D (2015) Efficacy of a Novel Fenugreek Seed Extract (Trigonella foenum-graecum, FurocystTM) in Polycystic Ovary Syndrome (PCOS) Int J Med Sci 12 825-31

Taliyan R and Sharma P L (2012) Protective effect and potential mechanism of Ginkgo biloba extract EGb 761 on STZinduced neuropathic pain in rats Phytother Res 26 18231829

Taprial S, Kashyap D, Mehta V, Kumar S and Kumar D (2013) Antifertility effect of hydroalcoholic leaves extract of Michelia champaca L.: An ethnomedicine used by Bhatra women in Chhattisgarh state of India J Ethnopharmacol 147 671-675

Tapryal N, Vivek G V and Mukhopadhyay C K (2015) Catecholamine stress hormones regulate cellular iron homeostasis by a posttranscriptional mechanism mediated by iron regulatory protein: implication in energy homeostasis J Biol Chem 290 7634-7646

Thakur A K, Soni U K, Rai G, Chatterjee S S and Kumar V (2014) Protective effects of Andrographis paniculata extract and pure andrographolide against chronic stress-triggered pathologies in rats Cell Mol Neurobiol 34 1111-1121

Thiyagarajan G, Muthukumaran P, Sarath Kumar B, Muthusamy V S and Lakshmi B S (2016) Selective Inhibition of PTP1B by Vitalboside A from Syzygium cumini Enhances Insulin Sensitivity and Attenuates Lipid Accumulation Via Partial Agonism to PPARgamma: In Vitro and In Silico Investigation Chem Biol Drug Des 88 302-312 
Tiwari D and Vanage G (2013) Mutagenic effect of Bisphenol A on adult rat male germ cells and their fertility Reprod Toxicol 40 60-68

Tiwari D and Vanage G (2017) Bisphenol A Induces Oxidative Stress in Bone Marrow Cells, Lymphocytes, and Reproductive Organs of Holtzman Rats Int J Toxicol 36 142-152

Trivedi P P and Jena G B (2013) Melatonin reduces ulcerative colitis-associated local and systemic damage in mice: investigation on possible mechanisms Dig Dis Sci 583460 3474

Trivedi P P, Jena G B, Tikoo K B and Kumar V (2016) Melatonin modulated autophagy and $\mathrm{Nrf} 2$ signaling pathways in mice with colitis-associated colon carcinogenesis Mol Carcinog 55 255-267

Unnikrishnan R, Anjana R M and Mohan V (2016) Diabetes mellitus and its complications in India Nat Rev Endocrinol 12 357-370

Upadhyay G, Khoshla S, Kosuru R and Singh S (2016) Anxiolytic, antidepressant, and antistress activities of the aqueous extract of Cinnamomum tamala Nees and Eberm in rats Indian J Pharmacol 48 555-561

Upreti V, Somani S and Kotwal N (2017) Efficacy of Teriparatide in Patients with Hypoparathyroidism: A Prospective, Open-label Study Indian J Endocrinol Metab 21 415-418

Vanitha P, Senthilkumar S, Dornadula S, Anandhakumar S, Rajaguru P and Ramkumar K M (2017) Morin activates the Nrf2-ARE pathway and reduces oxidative stressinduced DNA damage in pancreatic beta cells Eur $J$ Pharmacol 801 9-18

Vanitha P, Uma C, Suganya N, Bhakkiyalakshmi E, Suriyanarayanan S, Gunasekaran P, Sivasubramanian S and Ramkumar K M (2014) Modulatory effects of morin on hyperglycemia by attenuating the hepatic key enzymes of carbohydrate metabolism and beta-cell function in streptozotocin-induced diabetic rats Environ Toxicol Pharmacol 37 326-335

Verma H P and Singh S K (2014) Effect of aqueous leaf extract of Dalbergia sissoo Roxb. on spermatogenesis and fertility in male mice Eur J Contracept Reprod Health Care 19475 486

Verma H P and Singh S K (2017) Antifertility efficacy of Coccinia indica in male mice and its possible mechanisms of action on spermatogenesis Gen Comp Endocrinol 241 89-99

Verma M K, Biswas S, Chandravanshi B, Neelima K, Oommen A M, Jagannath M R and Somesh B P (2014) A novel GPR40 agonist, CNX-011-67, suppresses glucagon secretion in pancreatic islets under chronic glucolipotoxic conditions in vitro BMC Res Notes 7595

Verma M K, Sadasivuni M K, Yateesh A N, Neelima K, Mrudula S, Reddy M, Smitha R, Biswas S, Chandravanshi B, Pallavi P M, Oommen A M, Jagannath M R and Somesh B B (2014) Activation of GPR40 attenuates chronic inflammation induced impact on pancreatic beta-cells health and function BMC Cell Biol 1524

Verma R and Krishna A (2017) Effect of tamoxifen on spermatogenesis and testicular steroidogenesis Biochem Biophys Res Commun 486 36-42

Verma R and Krishna A (2017) Effect of Letrozole, a selective aromatase inhibitor, on testicular activities in adult mice: Both in vivo and in vitro study Gen Comp Endocrinol 241 $57-68$

Vishnoi S, Raisuddin S and Parvez S (2016) Glutamate Excitotoxicity and Oxidative Stress in Epilepsy: Modulatory Role of Melatonin J Environ Pathol Toxicol Oncol 35 365-374

Vishwas D K, Mukherjee A and Haldar C (2013) Melatonin improves humoral and cell-mediated immune responses of male golden hamster following stress induced by dexamethasone J Neuroimmunol 259 17-25

Viswanathan C and Sarang S (2013) Status of stem cell based clinical trials in the treatment for diabetes Curr Diabetes $\operatorname{Rev} 9$ 429-436

Vyas B A, Desai N Y, Patel P K, Joshi S V and Shah D R (2013) Effect of Boerhaavia diffusa in experimental prostatic hyperplasia in rats Indian J Pharmacol 45264

Vyas N Y and Raval M A (2016) Aphrodisiac and spermatogenic potential of alkaloidal fraction of Hygrophila spinosa T. Ander in rats $J$ Ethnopharmacol 194 947-953

Waseem M, Sahu U, Salman M, Choudhury A, Kar S, Tabassum H and Parvez S (2017) Melatonin pre-treatment mitigates SHSY-5Y cells against oxaliplatin induced mitochondrial stress and apoptotic cell death PLoS One 12 e0180953

Yadav D, Chaudhary A A, Garg V, Anwar M F, Rahman M M, Jamil S S, Khan H A and Asif M (2013) In vitro toxicity and antidiabetic activity of a newly developed polyherbal formulation (MAC-ST/001) in streptozotocin-induced diabetic Wistar rats Protoplasma 250 741-749

Yerra V G and Kumar A (2017) Adenosine MonophosphateActivated Protein Kinase Abates Hyperglycaemia-Induced Neuronal Injury in Experimental Models of Diabetic Neuropathy: Effects on Mitochondrial Biogenesis, Autophagy and Neuroinflammation Mol Neurobiol 54 2301-2312. 